\title{
Methodological exploration of bone marrow stem cell therapy in acute myocardial infarction - how to achieve greater benefit on cardiac outcomes: A systematic review and meta-analysis
}

\author{
Mei Yang ${ }^{A-F}$, Quanfu Xü ${ }^{A-F}$, Bo Liu ${ }^{B, C, E}$, Xiu Chen ${ }^{B, C}$, Yigang Li ${ }^{A, E, F}$ \\ Department of Cardiology, Xinhua Hospital affiliated to Shanghai Jiaotong University School of Medicine, Shanghai, China \\ A - research concept and design; $B$ - collection and/or assembly of data; C - data analysis and interpretation; \\ $D$ - writing the article; $E$ - critical revision of the article; $F$ - final approval of the article
}

Address for correspondence

Yigang Li

E-mail: occjizheng@126.com

Funding sources

Shanghai Committee of Science and Technology

of China (14YF1402900).

Conflict of interest

None declared

Received on February 2, 2016

Reviewed on August 31,2016

Accepted on 0ctober 26, 2016

DOI

\section{Abstract}

Background. Clinical trials of intracoronary injection of bone marrow-derived stem cells (BMCs) in patients with acute myocardial infarction (AMI) have revealed promising but variable and modest results. One of the reasons underlying this situation may be the unstandardized preparation of BMCs.

Objectives. The aim of this study was to explore whether methodological differences affect the prognosis of acute myocardial infarction patients who received BMCs transplantation.

Material and methods. MEDLINE was searched for randomized controlled trials providing AMI patients with intracoronary BMCs injection or a standard therapy. Changes in cardiac parameters and clinical outcomes were analyzed. Subgroup analyses were conducted according to different methodologies for cell preparation, including supplement for serum or plasma, use of heparin and cell washout.

Results. Non-use of serum or plasma in the cell suspension is associated with more reduction in infarct size (IS) and a lower risk of all-cause mortality. Heparin usage could diminish the benefit in reducing IS. All-cause mortality rose significantly without the cell washout procedure when heparin was used.

Conclusions. Methodological differences in BMCs preparation as well as the use of heparin and serum/ plasma impact on the prognosis of AMl patients.

Key words: acute myocardial infarction, bone marrow-derived stem cells transplantation, cell preparation, serum or plasma, heparin

\subsection{9/acem/66385}




\section{Introduction}

Clinical trials of intracoronary injection of bone marrow-derived stem cells (BMCs) in patients with acute myocardial infarction (AMI) have revealed promising results. However, improved left ventricular ejection fraction (LVEF) and left ventricular remodeling were observed in most but not all studies. Moreover, the extent of improvement was variable between the trials and the benefit of cell therapy

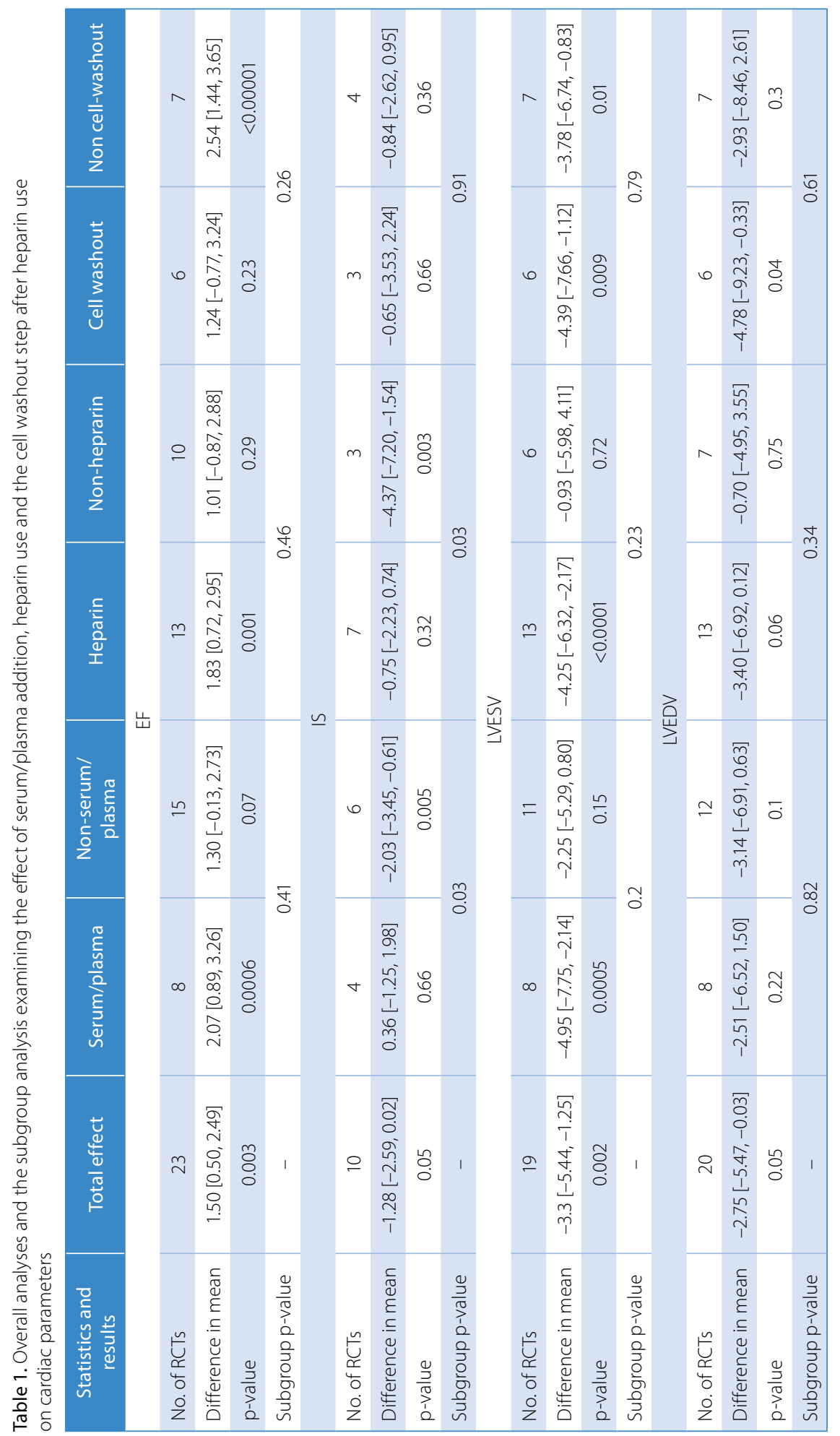

with BMCs was modest. One reason underlying the variable and modest improvement of cardiac function by cell therapy may be related to the unstandardized preparation of BMCs. Serum or plasma, which in some trials was used to provide a suitable physiological environment for BMCs, was reported to induce clotting of the cell product. Similarly heparin, used to prevent coagulation during cell preparation in many clinical trials, has recently been shown to affect the survival and functionality of BMCs. Therefore, the objective of this systematic review and meta-analysis is to explore whether the usage of serum or plasma, heparin and steps of washout during cell preparation may have influenced the results of previous trials.

\section{Methods}

\section{Search strategy}

We searched MEDLINE for studies of BMCs transplantation in patients with acute myocardial infarction by November 2015 using the following terms: "randomized controlled trials"; "cell therapy"; "stem cells"; "progenitor cells"; "precursor cells"; "bone marrow cells"; "mononuclear cells"; "cell transplantation"; "coronary artery disease"; "myocardial infarction"; "acute myocardial infarction"; and "myocardial ischemia".

\section{Study selection}

Since this was a study for exploring the methodology of cell transplantation, we prepared relatively strict criteria to avoid disturbance caused by different study design. Clinical trials were included if they 1) were randomized controlled clinical trials; 2) were conducted on patients with acute myocardial infarction who accepted primary percutaneous coronary intervention (PCI); 3) were using BMCs for cell transplantation; 4) were conducting cell therapy by injecting BMCs into the infarct-related coronary artery; 5) were providing a standard therapy for patients in both control and intervention group; 6) provided a detailed description of cell preparation; and if (7) the ratio of loss to follow-up was $<20 \%$. Only articles published 
in English were included. We used mean and standard deviation for statistical analysis, so studies reporting data as median and range were not included.

\section{Data extraction}

Two investigators independently screened all the titles and abstracts to include studies that met our inclusion criteria, and extracted the data from the papers. When there were disagreements, a third investigator was involved. Inclusion criteria or data would be reviewed and discussed until final decisions were made.

The cardiac outcome measures included changes in LVEF, infarct size (IS), left ventricular end-systolic volume (LVESV), and left ventricular end-diastolic volume (LVEDV). The clinical outcome measures from follow-ups included cardiac mortality, all-cause mortality, reinfarction, target-vessel restenosis, all-vessel restenosis,

Table 2. Overall analyses and the subgroup analysis examining the effect of serum/plasma addition, heparin use and the cell washout step after heparin use on clinical outcomes

\begin{tabular}{|c|c|c|c|c|c|c|c|}
\hline \multirow{2}{*}{$\begin{array}{l}\text { Statistics and } \\
\text { results }\end{array}$} & \multirow[b]{2}{*}{ Total effect } & \multicolumn{2}{|c|}{ Supplement } & \multicolumn{2}{|c|}{ Heparin usage } & \multicolumn{2}{|c|}{ Cell washout } \\
\hline & & serum/plasma & $\begin{array}{c}\text { non-serum/ } \\
\text { plasma }\end{array}$ & heparin & non-heparin & cell washout & $\begin{array}{l}\text { non-cell } \\
\text { washout }\end{array}$ \\
\hline \multicolumn{8}{|c|}{ Cardiac death } \\
\hline Peto OR & $0.41[0.13,1.27]$ & $0.81[0.11,5.95]$ & $0.39[0.13,1.17]$ & $0.50[0.12,2.04]$ & $0.29[0.04,1.91]$ & $0.24[0.03,1.78]$ & $1.01[0.14,7.22]$ \\
\hline$p$-value & 0.12 & - & - & - & - & - & - \\
\hline Subgroup p-value & - & \multicolumn{2}{|c|}{0.42} & \multicolumn{2}{|c|}{0.65} & \multicolumn{2}{|c|}{0,31} \\
\hline \multicolumn{8}{|c|}{ All-cause mortality } \\
\hline Peto OR & $1.01[0.49,2.08]$ & $3.01[0.97,9.31]$ & $0.47[0.18,1.21]$ & $1.35[0.60,3.03]$ & $0.33[0.07,1.64]$ & $0.47[0.13,1.68]$ & $2.73[0.96,7.78]$ \\
\hline$p$-value & 0.98 & - & - & - & - & - & - \\
\hline Subgroup p-value & - & \multicolumn{2}{|c|}{0.01} & \multicolumn{2}{|c|}{0.13} & \multicolumn{2}{|c|}{0.04} \\
\hline \multicolumn{8}{|c|}{ Reinfarction } \\
\hline Peto OR & $0.49[0.22,1.09]$ & $0.24[0.08,0.71]$ & $1.03[0.30,3.58]$ & $0.45[0.18,1.08]$ & $0.76[0.12,4.87]$ & $0.72[0.22,2.33]$ & $0.23[0.06,0.90]$ \\
\hline p-value & $0, .06$ & - & - & - & - & - & - \\
\hline Subgroup p-value & - & \multicolumn{2}{|c|}{0.09} & \multicolumn{2}{|c|}{0.61} & \multicolumn{2}{|c|}{0.22} \\
\hline \multicolumn{8}{|c|}{ Target-vessel restenosis } \\
\hline Peto OR & $0.96[0.66,1.40]$ & $0.91[0.56,1.50]$ & $1.03[0.58,1.84]$ & $1.00[0.67,1.50]$ & $0.77[0.33,1.82]$ & $1.13[0.64,1.99]$ & $0.88[0.48,1.61]$ \\
\hline$p$-value & 0.2 & - & - & - & - & - & - \\
\hline Subgroup p-value & - & \multicolumn{2}{|c|}{0.75} & \multicolumn{2}{|c|}{0.62} & \multicolumn{2}{|c|}{0.55} \\
\hline \multicolumn{8}{|c|}{ All-vessel restenosis } \\
\hline Peto OR & $0.96[0.71,1.31]$ & $0.81[0.54,1.23]$ & $1.17[0.75,1.81]$ & $0.97[0.70,1.35]$ & $0.92[0.42,2.02]$ & $1.14[0.71,1.83]$ & $0.84[0.54,1.33]$ \\
\hline$p$-value & 0.82 & - & - & - & - & - & - \\
\hline Subgroup p-value & - & \multicolumn{2}{|c|}{0.24} & \multicolumn{2}{|c|}{0.91} & \multicolumn{2}{|c|}{0.38} \\
\hline \multicolumn{8}{|c|}{ Stent thrombosis } \\
\hline Peto OR & $0.65[0.22,1.89]$ & $0.58[0.17,1.90]$ & $1.06[0.09,12.07]$ & $0.65[0.20,2.05]$ & $0.66[0.04,11.84]$ & $0.99[0.20,5.01]$ & $0.42[0.08,2.15]$ \\
\hline p-value & 0.43 & - & - & - & - & - & - \\
\hline Subgroup p-value & & & & & & & \\
\hline & & & Heart $f$ & ilure & & & \\
\hline Peto OR & $0.72[0.39,1.33]$ & $0.64[0.19,2.15]$ & $0.75[0.37,1.53]$ & $0.64[0.33,1.24]$ & $1.42[0.29,6.80]$ & $0.41[0.16,1.09]$ & $0.95[0.38,2.40]$ \\
\hline p-value & 0.3 & - & - & - & - & - & - \\
\hline Subgroup p-value & - & & & & & & \\
\hline & & & VT/syncope/ICL & implantation & & & \\
\hline Peto OR & $0.79[0.41,1.51]$ & $0.76[0.26,2.20]$ & $0.80[0.35,1.84]$ & $0.76[0.35,1.66]$ & $0.85[0.26,2.82]$ & $0.76[0.27,2.11]$ & $0.76[0.23,2.56]$ \\
\hline p-value & 0.47 & - & - & - & - & - & - \\
\hline Subgroup p-value & - & & & & & & \\
\hline & & & Stro & & & & \\
\hline Peto OR & $0.65[0.18,2.36]$ & $0.49[0.08,2.96]$ & $0.88[0.14,5.56]$ & $0.78[0.15,3.99]$ & $0.49[0.06,3.94]$ & $1.92[0.20,18.59]$ & $0.29[0.03,3.11]$ \\
\hline$p$-value & 0.51 & - & - & - & - & - & - \\
\hline Subgroup p-value & - & & & & & & \\
\hline
\end{tabular}


stent thrombosis, heart failure, ventricular arrhythmia/ syncope/ICD implantation, and stroke. Data with the longest duration of follow-up were extracted as outcome measures. IS was defined as the ratio of infarct region to left ventricle. Left ventricular volumes were estimated from LV volume indexes when appropriate. Multiple imaging modalities were used in some studies. When available, data from MRI or SPECT was preferred for analyses to data from echocardiography or left ventricular angiography.

Data processing was done using the methods described in the Cochrane handbook when needed. For studies with more than one intervention arms, with different doses of BMCs or different time for intervention, outcome measures data was combined. For studies that did not report changes in outcome measures between baseline and follow-up, the mean differences and standard deviations were calculated using data from a reference study with presented mean and standard deviation for baseline and final measures as well as for changes from the baseline.

\section{Data analysis}

Statistical analyses were performed with Cochrane RevMan v. 5.2.11 (Cochrane, London, UK), and the results were expressed as weighted mean differences for continuous outcomes with 95\% confidence intervals (CIs). Data was pooled by a random effects model. Because of low incidence of clinical cardiovascular events during followup and low heterogeneity, Peto OR was applied to obtain an overall estimate of the odds ratio for clinical outcomes, assuming fixed effects. Heterogeneity was analyzed with the $\mathrm{I}^{2}$ statistic, and was defined as low (25\%-50\%), intermediate $(50 \%-75 \%)$, or high $(>75 \%)$. The p-values $<0.05$ (2-sided) were considered as statistically significant. Funnel plots were constructed to explore publication bias.

\section{Quality assessment}

The criteria established by Juni et al. were used to assess the quality of studies included, which were all randomized controlled clinical trials. ${ }^{1}$

\section{Subgroup analysis for methodological exploration}

To determine whether one particular procedure of cell preparation may impact the outcomes, subgroup analyses were conducted based on 1) the supplement of serum or plasma to the cell suspension or not; 2) the use of heparin in the cell suspension or not ('use' was defined as mixing BMCs with heparin during cell preparation); 3) cell washout or not after mixing with heparin during cell preparation.

\section{Results}

\section{Search results}

The initial search retrieved 1,126 reports with our search strategy. The majority of reports were excluded

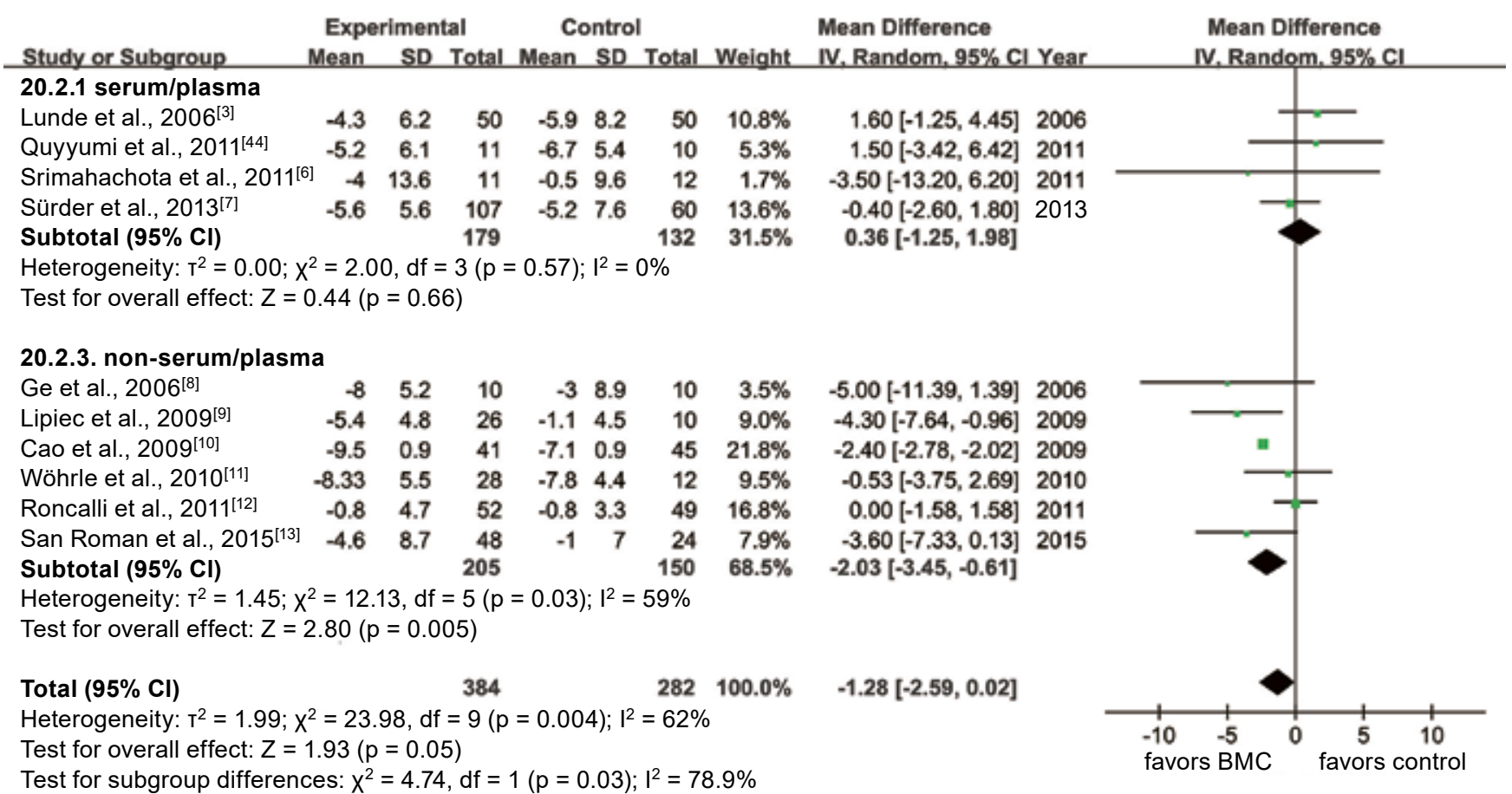

Fig. 1. Forest plot of the subgroup analysis of unadjusted difference in mean change in IS (with 95\% Cls) among the trials using serum/plasma as a supplement for cell suspension or other supplements during BMCs preparation (the outcome was statistically in favor of non-use of serum/ plasma for cell preparation) ${ }^{3-13}$ 
due to other types of study subjects (like chronic heart failure or granulocyte-colony stimulating factor treatment), wrong language, because they were reviews, or were regarded irrelevant on the basis of title and abstract. Full texts of 69 reports were thoroughly analyzed, and 36 reports were further excluded as being not randomized controlled trials, unmatched cell therapy approaches (like intramyocardial injection), a substudy, multiple publications, or without relevant outcomes. Two studies were excluded after full text analysis on account of an incomplete description of cell collection and preparation. One study was omitted because of a high percentage of loss to followup. Another study was excluded from this meta-analysis, because every patient in the cell therapy group received BMCs transplantation (or placebo) twice. The remaining 29 reports (24 clinical trials and 1,728 patients) were eventually included in this meta-analysis. All studies reported
LVEF before and after cell transplantation in patients from both the cell therapy and control group, with or without other cardiac parameters and clinical outcomes.

\section{Study characteristics}

The median follow-up duration was 13 months (range: 3-61 months) and the median sample size was 72 patients (range: $10-204$ patients). Only 7 (29.2\%) studies included patients with acute anterior myocardial infarction, and the other studies were nonselective about the infarction segment. Based on the mean range of time from the onset of symptoms to PCI, the majority of patients underwent primary PCI in $24 \mathrm{~h}$, while 3 studies did not give this data in their reports. Most patients cell therapy arm received cell transplantation within 7 days after AMI. Several imaging modalities were involved in these studies, including

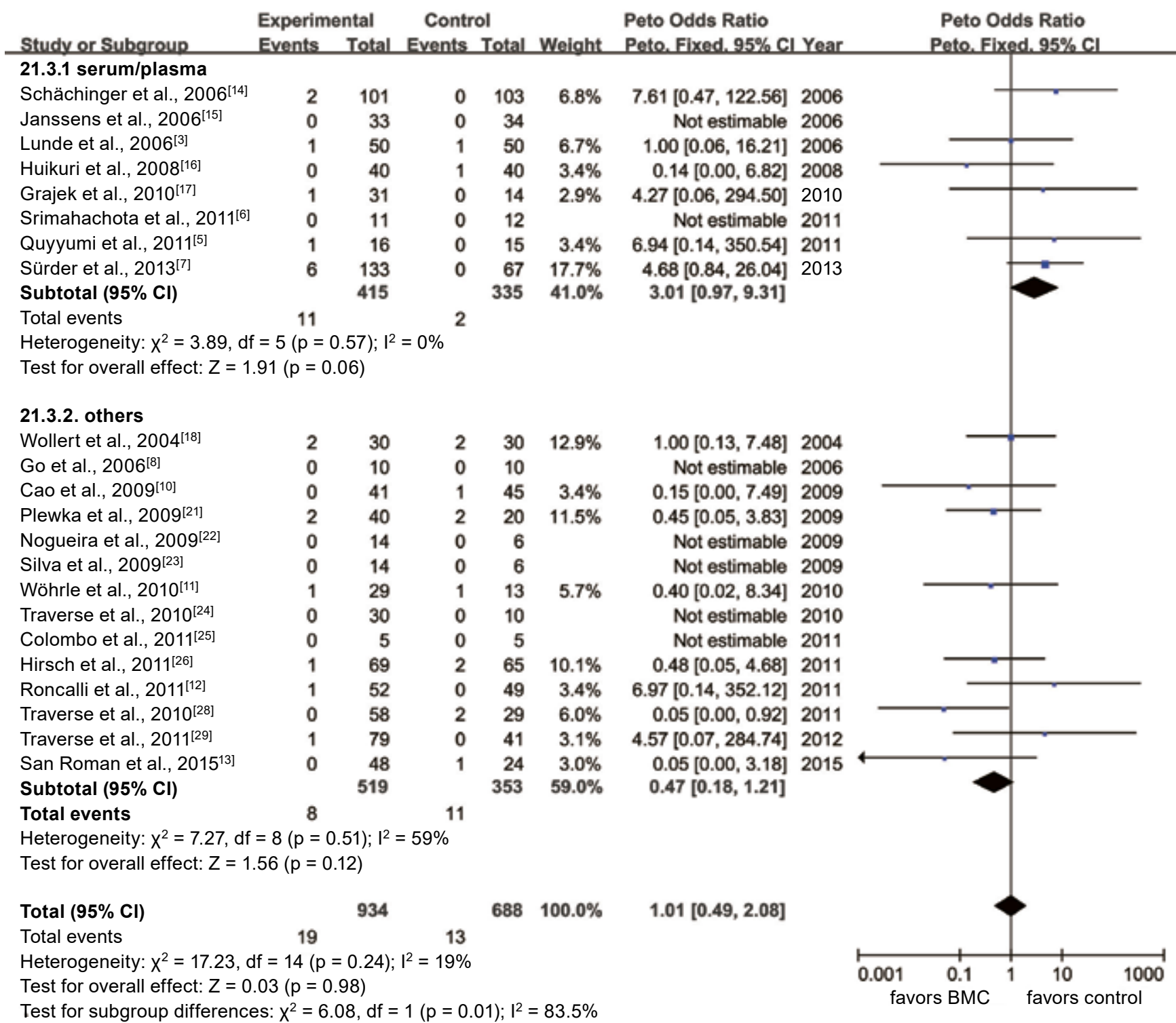

Fig. 2. Forest plot of the subgroup analysis of Peto OR in all-cause mortality among the trials using serum/plasma as a supplement for cell suspension or other supplements during BMCs preparation (the outcome was statistically in favor of non-use of serum/plasma for cell preparation) ${ }^{14-30}$ 


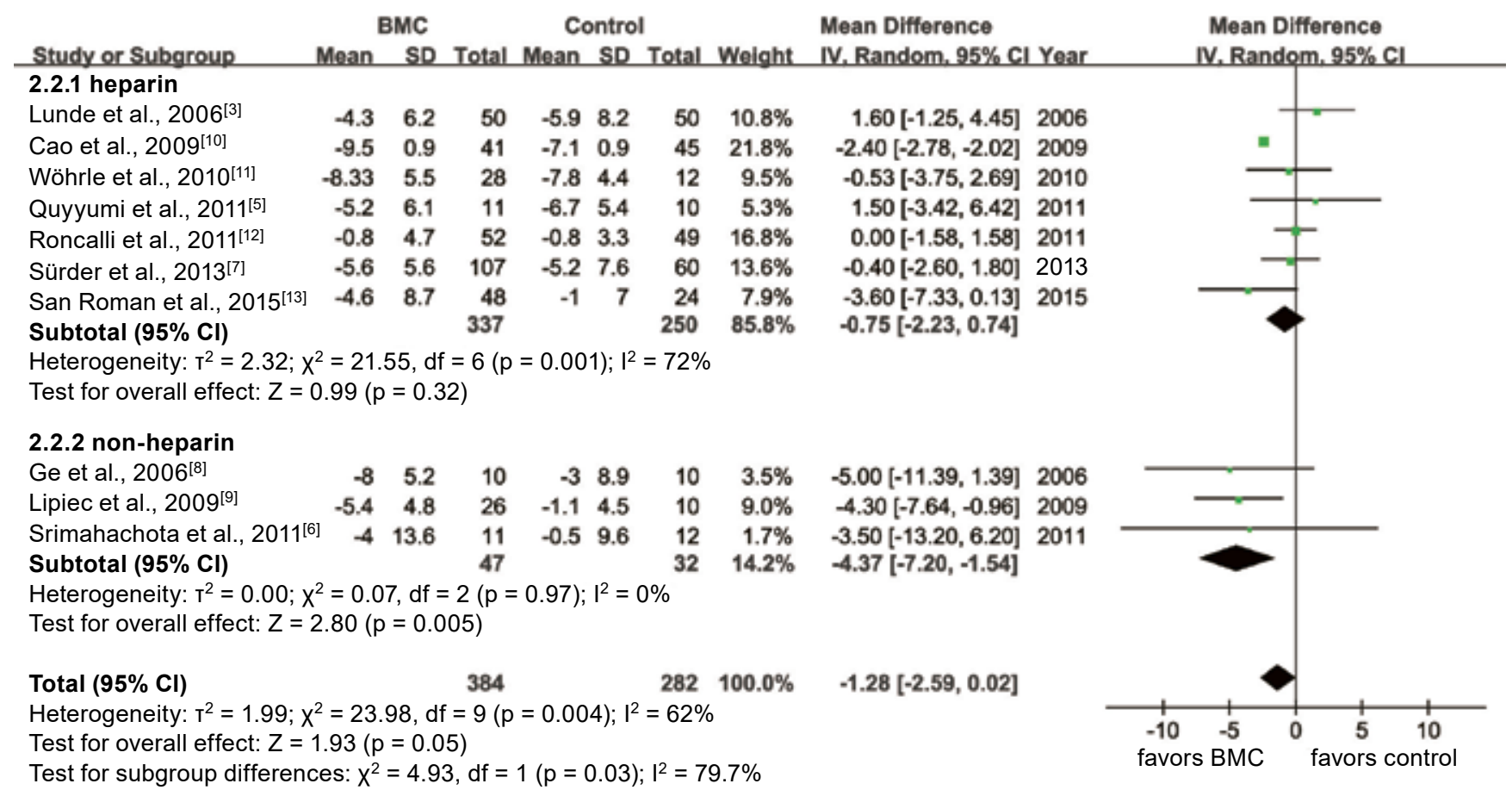

Fig. 3. Forest plot of the subgroup analysis of unadjusted difference in mean change in IS (with $95 \% \mathrm{Cls}$ ) among the trials using heparin or not during BMCs preparation (the outcome was statistically in favor of non-use of heparin for cell preparation)

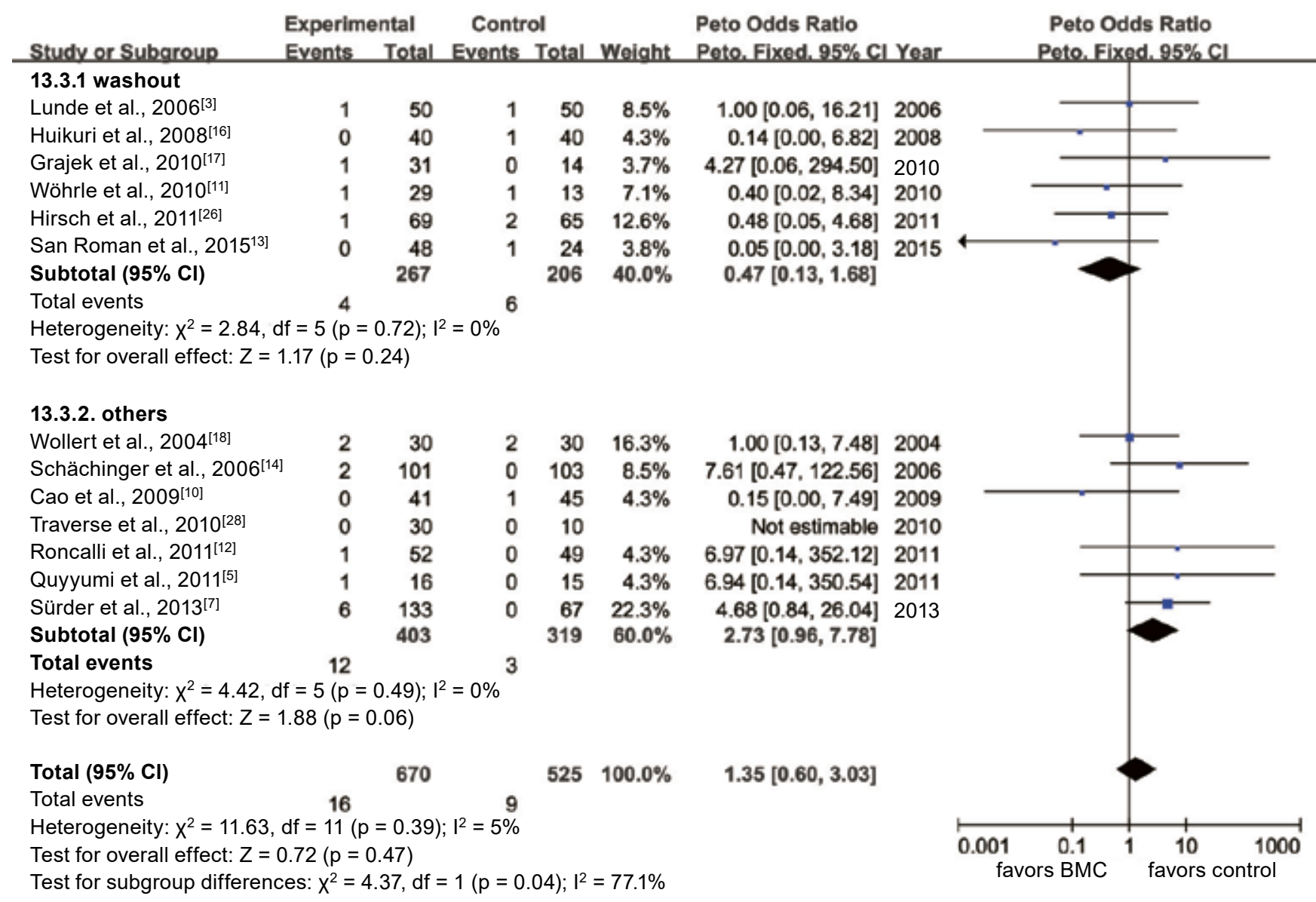

Fig. 4. Forest plot of the subgroup analysis of Peto OR in all-cause mortality among all the trials performing the cell washout step or not after heparin use during BMCs preparation (the outcome was statistically in favor of non-use of heparin for cell preparation) 
transthoracic echocardiography, SPECT, cardiac MRI and left ventricular angiography. MRI was used for conducting measurements in 13 (54.2\%) studies (Supplemental Table A).

\section{Study quality}

All studies were assessed using the Juni criteria (Supplemental Table B). All studies undertook adequate allocation and $79 \%$ of them provided detailed information about the method of randomization. Seven (29.2\%) studies were double-blinded and 2 (8.3\%) studies were single-blinded. Control patients did not undergo a sham biopsy and the infusion of cells in the other studies. Patient follow-up was completed in all studies. The percentage of patients lost to follow-up was acceptable.

\section{Sensitivity analysis}

The heterogeneity varied tremendously from low to high. The sensitivity analysis excluding 1 study at a time confirmed the results concerning all analyses in terms of direction and magnitude of statistical significance. The statistical heterogeneity $\left(\mathrm{I}^{2}\right)$ for LVEF vanished dramatically from $93 \%$ to $27 \%$, indicating low heterogeneity among the majority of the studies included, except for the study by Wang et al. ${ }^{2}$ Considering LVEF as the primary endpoint for almost all studies, this study was excluded in the following statistical analyses. After the exclusion, the heterogeneity for most cardiac parameters and all clinical outcomes was low.

\section{Cardiac parameters and clinical outcomes}

Only data with the longest duration of follow-up was referred to, although several follow-ups might have been conducted. Overall, BMCs transplantation to infarct-related region through the coronary artery was associated with statistically significant modification in all cardiac parameters (Table 1).

Twenty-three out of 24 studies conducted a follow-up and provided a clinical outcome in the reports. However, Peto OR results indicated no improvement in clinical outcomes in the cell therapy arm compared with the control arm (Table 2).

\section{Subgroup analysis}

\section{Supplement of cell suspension}

Many kinds of supplements were added to the final cell suspension such as serum, plasma, human serum albumin, phosphate-buffered saline, cell culture medium, etc. Whether serum or plasma was added was the only concern in this systematic review. Clinical trials which used serum/ plasma in the BMC suspension were compared with those that did not (Table 1). No subgroup difference was found in the LVEF, LVESV and LVEDV (Supplemental Fig. 1-3). However, statistic results indicated that cell suspension without serum/plasma tended to diminish the IS $(-2.03 \%$, $\mathrm{p}=0.005)$, while the subgroup with the serum/plasma addition showed no impact on IS change $(0.36 \% ; \mathrm{p}=0.66)$. The difference between the 2 subgroups was statistically significant ( $\mathrm{p}=0.03$ ) (Fig. 1).

Although there were no significant differences in clinical outcomes, when all clinical trials included were considered, the analyses of subgroup differences showed that serum/plasma addition might increase all-cause mortality (Peto OR: 3.01; $\mathrm{p}=0.06$ ), which was significantly higher compared to non-serum/plasma subgroup (Peto OR: 0.47; $\mathrm{p}=0.01$ ) (Fig. 2). No other subgroup differences were found to be significant in the other clinical outcomes (Table 2).

\section{Anticoagulant usage}

Thirteen out of 23 studies used heparin during cell preparation to prevent coagulation. The remaining studies used no anticoagulant during the procedure. Anticoagulant other than heparin was not found to be used in any study. When use of heparin and non-use of heparin was compared between the subgroups, IS change in the non-heparin subgroup was much greater than in the heparin subgroup (non-heparin vs heparin: $-4.37 \%$ vs $-0.75 \%$; $\mathrm{p}=0.03$ ) (Fig. 3). No significant subgroup difference was found in LVEF, LVESV and LVEDV (Supplemental Fig. 4-6). Clinical outcomes were also compared between the 2 subgroups and no subgroup difference was found, either.

\section{Cell washout}

Thirteen studies added heparin into BMCs for coagulation, and in 6 of them, BMCs were further washed out before the final cell suspension for infection was obtained. In the case of studies with heparin usage, all cardiac parameters were compared between the studies with the cell washout application and those without. No subgroup difference was found in the cardiac parameters (Supplemental Fig. 7-10). With regard to clinical outcomes, all-cause mortality was increased in the non-washout subgroup (Peto OR: $2.73 ; \mathrm{p}=0.06)$ and the intra-subgroup differences were significant (Peto OR: 2.73 vs 0.47; $\mathrm{p}=0.04$ ) (Fig. 4).

\section{Discussion}

As far as we know, this is the first systematic review to focus on the impact of cell preparation on the efficacy and safety of intracoronary autologous BMCs transfer in patients with AMI. Firstly, this meta-analysis confirmed that, as compared with standard medical treatment, intracoronary BMCs therapy after AMI was associated with a significant increase in LVEF as well 


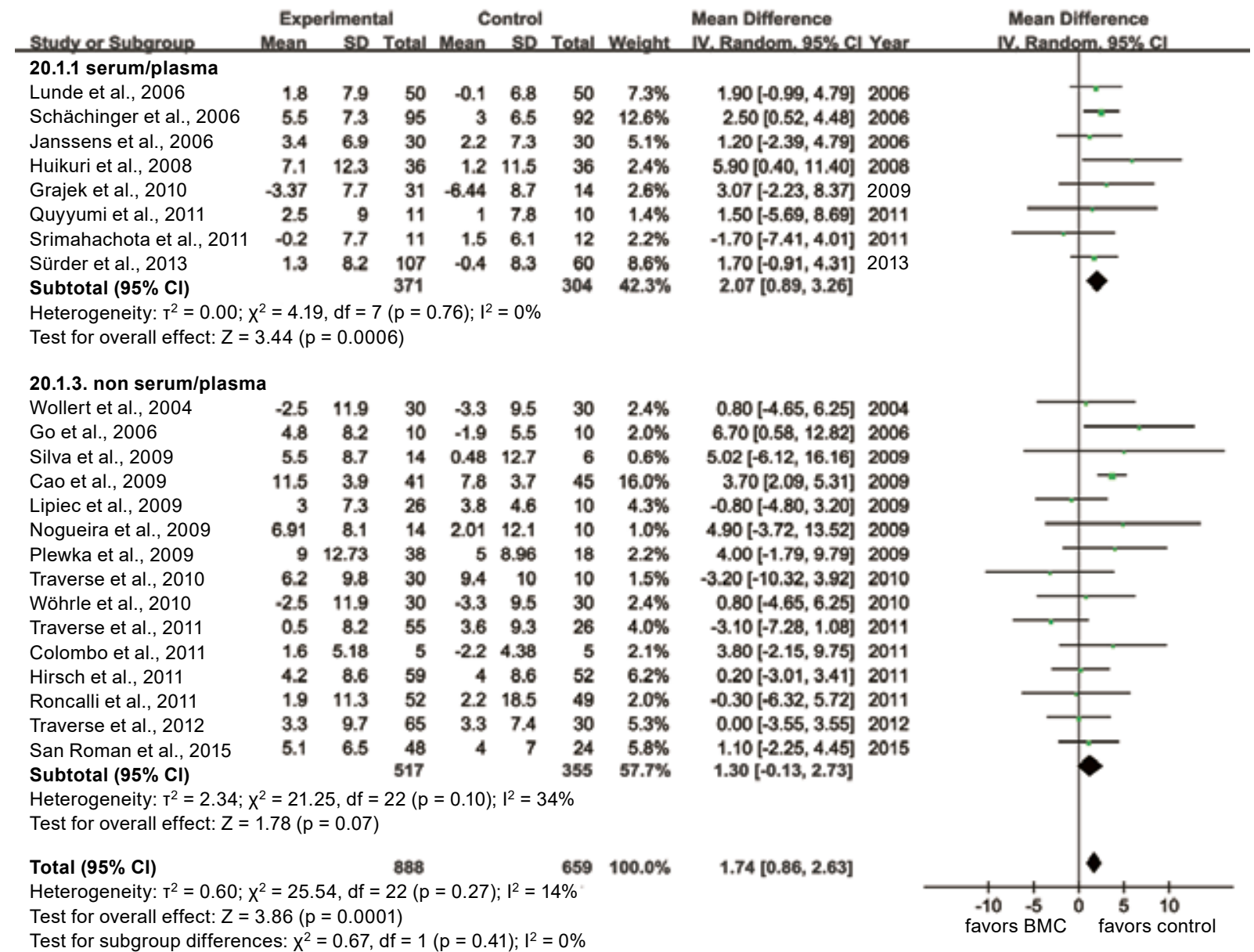

Supplemental Fig. 1.

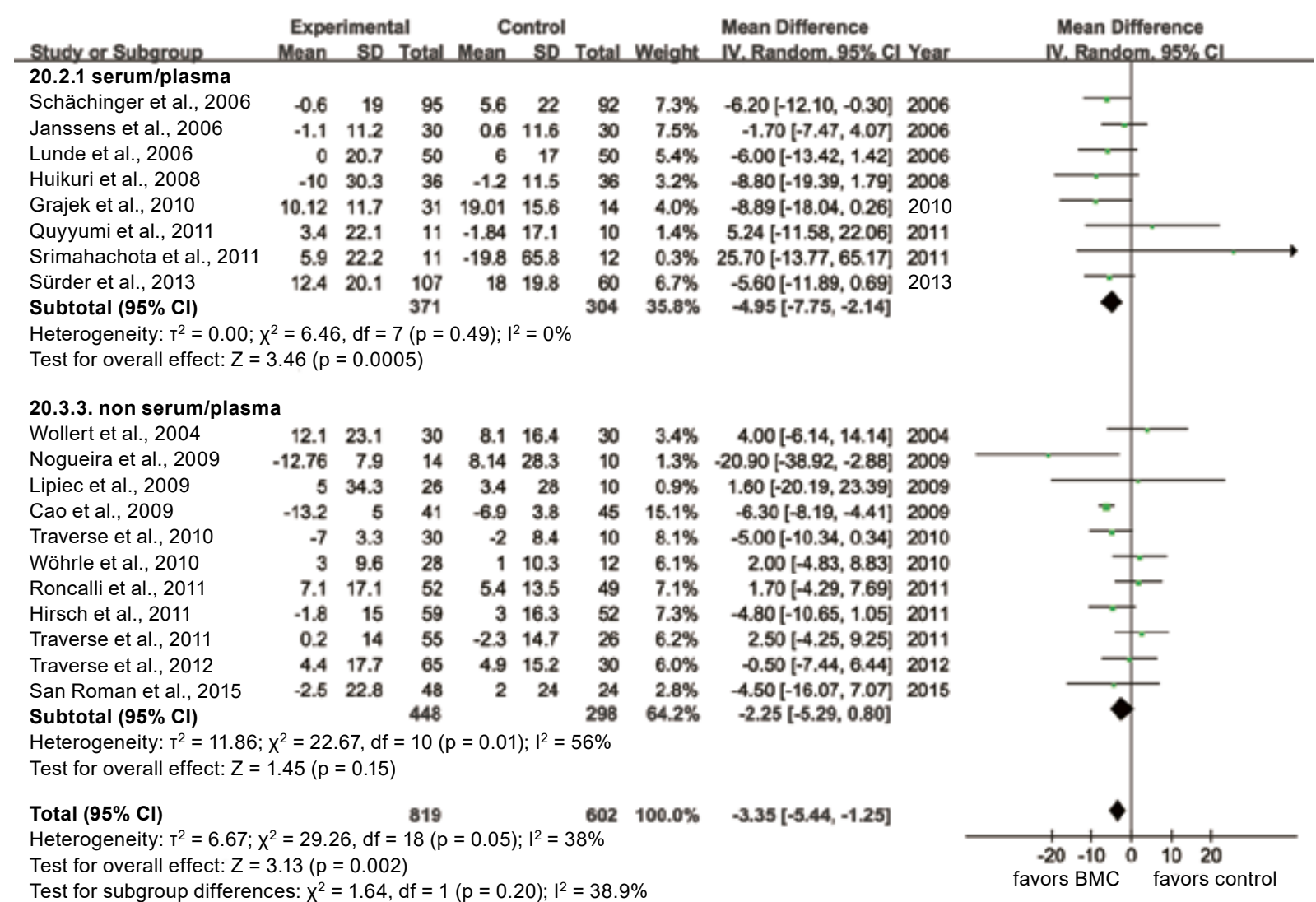

Supplemental Fig. 2. 


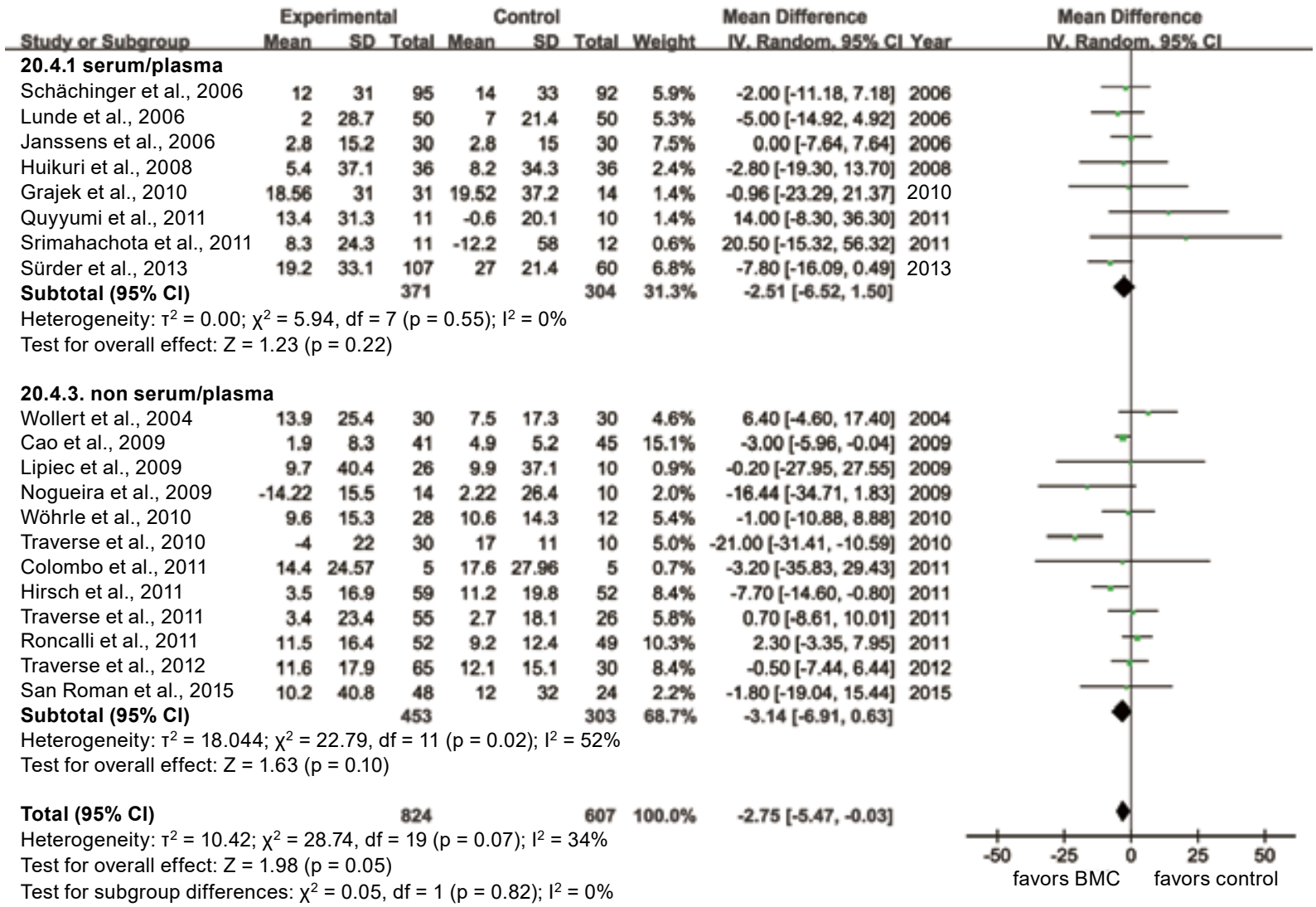

Supplemental Fig. 3.

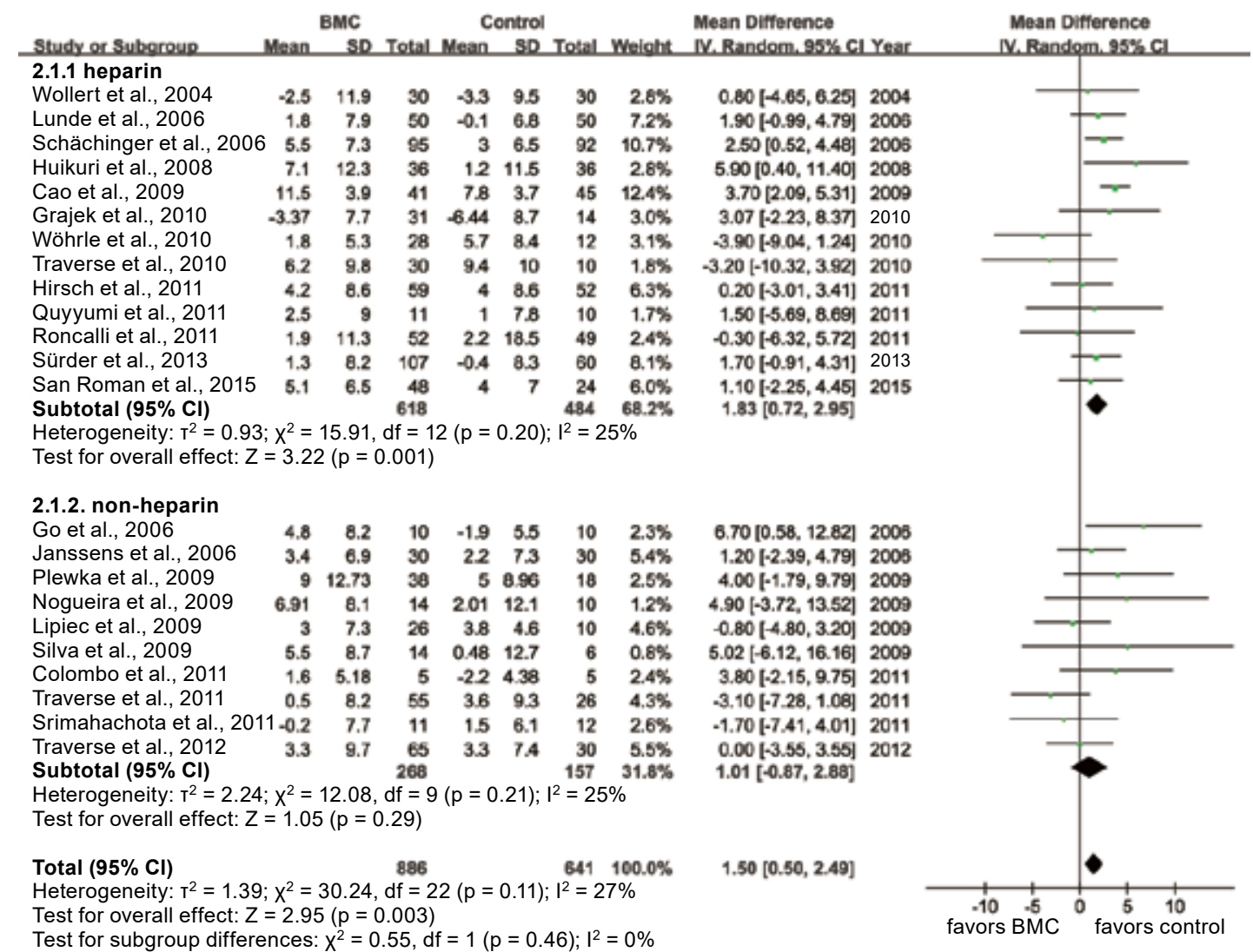

Supplemental Fig. 4. 


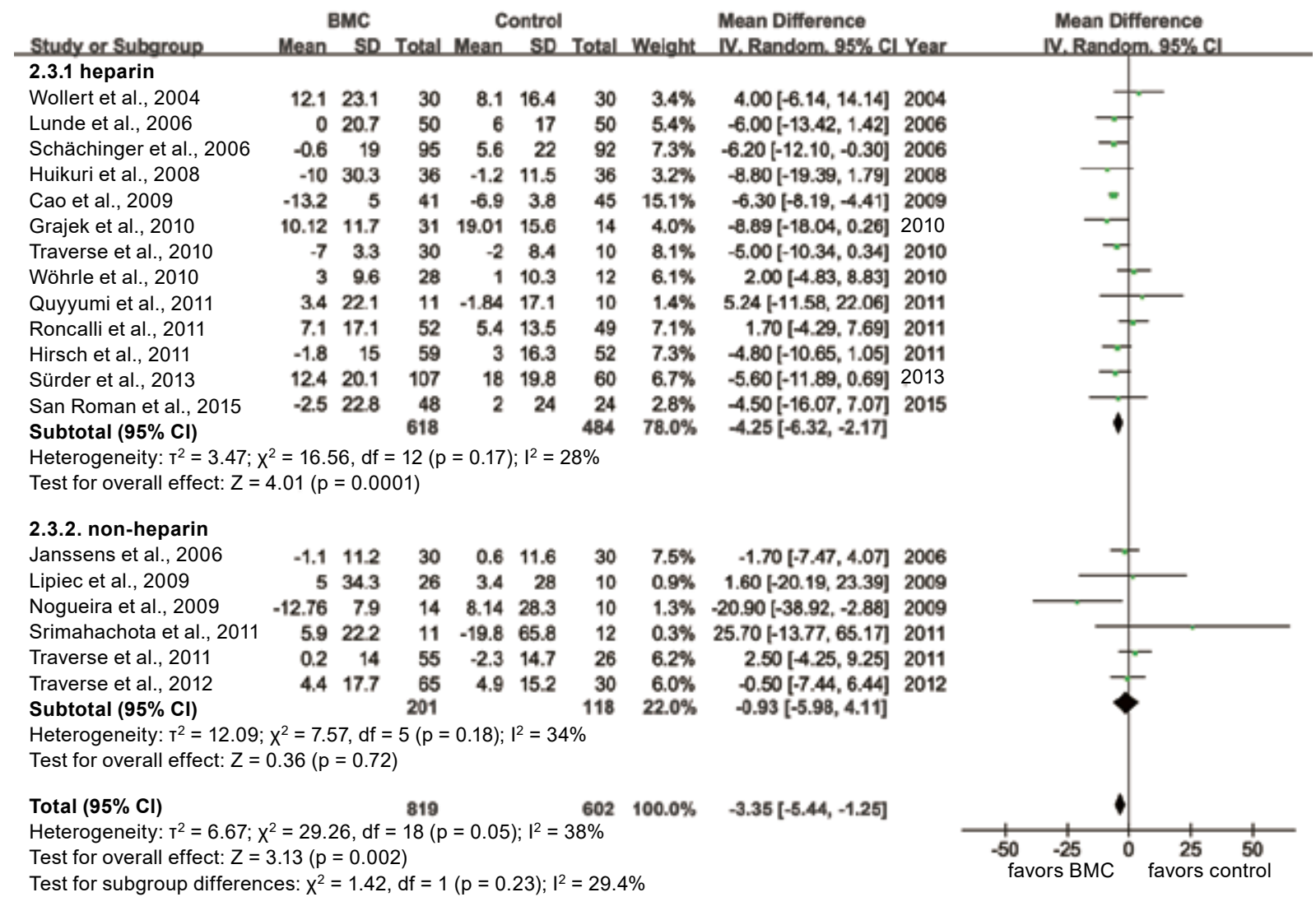

Supplemental Fig. 5.

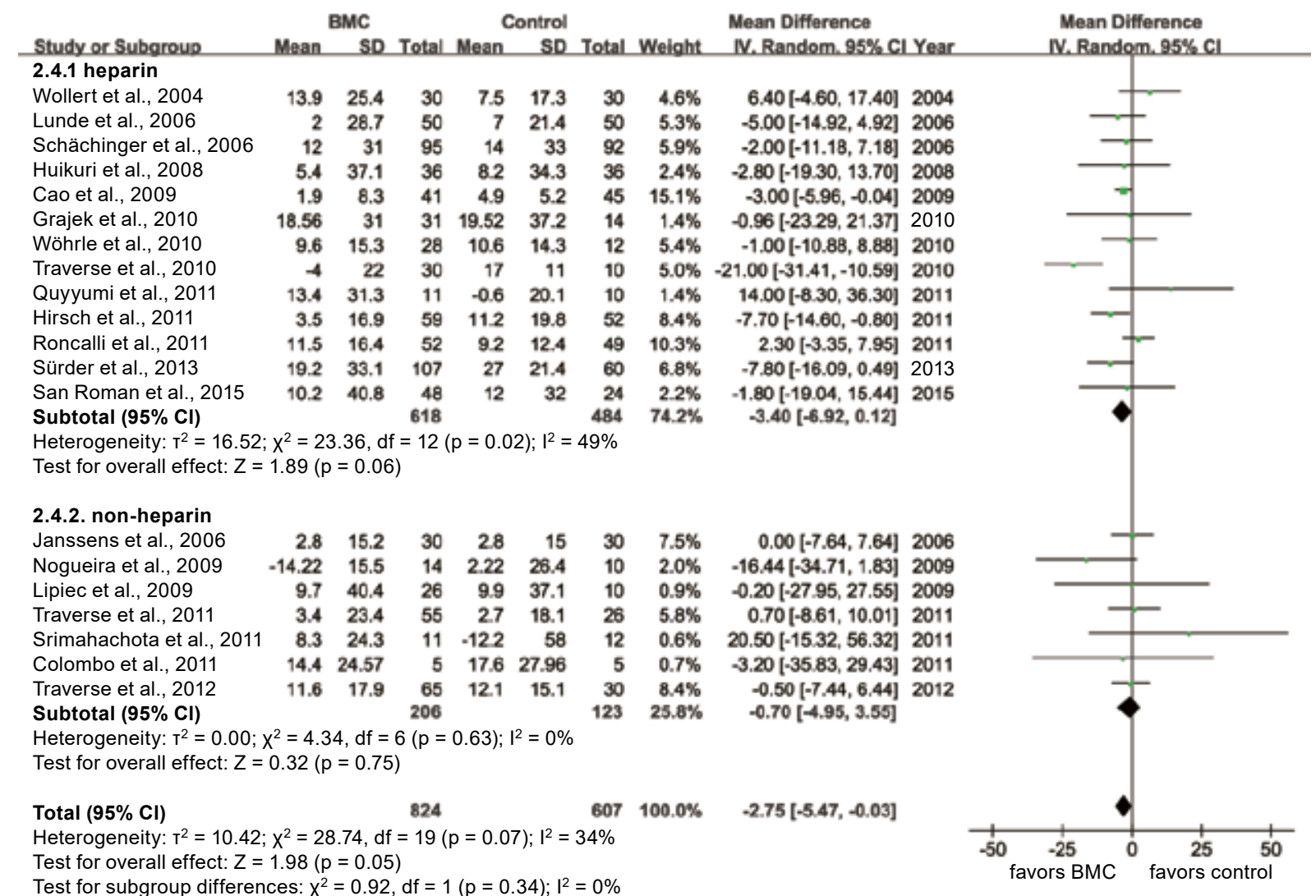

\footnotetext{
Supplemental Fig. 6.
} 


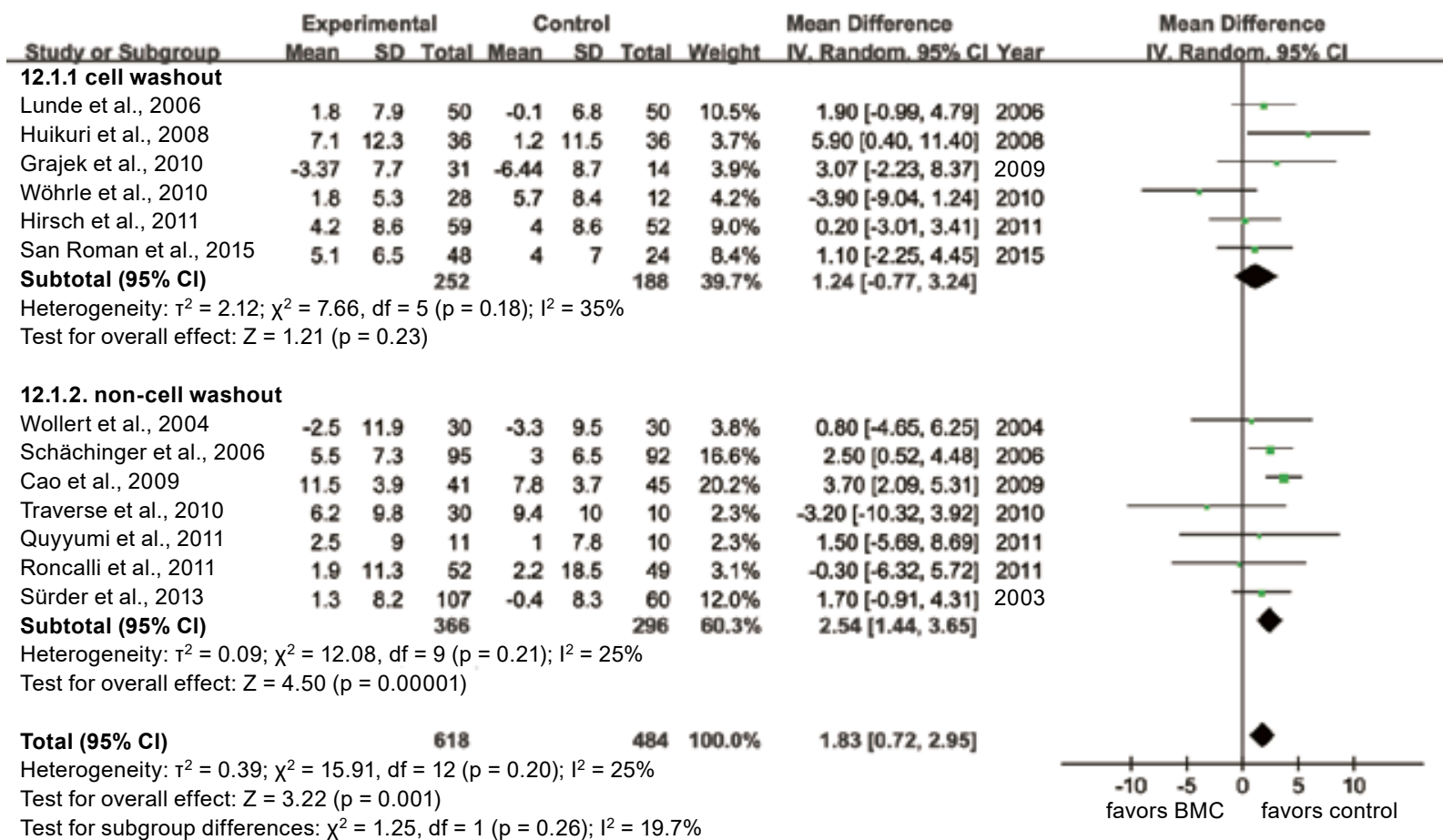

Supplemental Fig. 7.

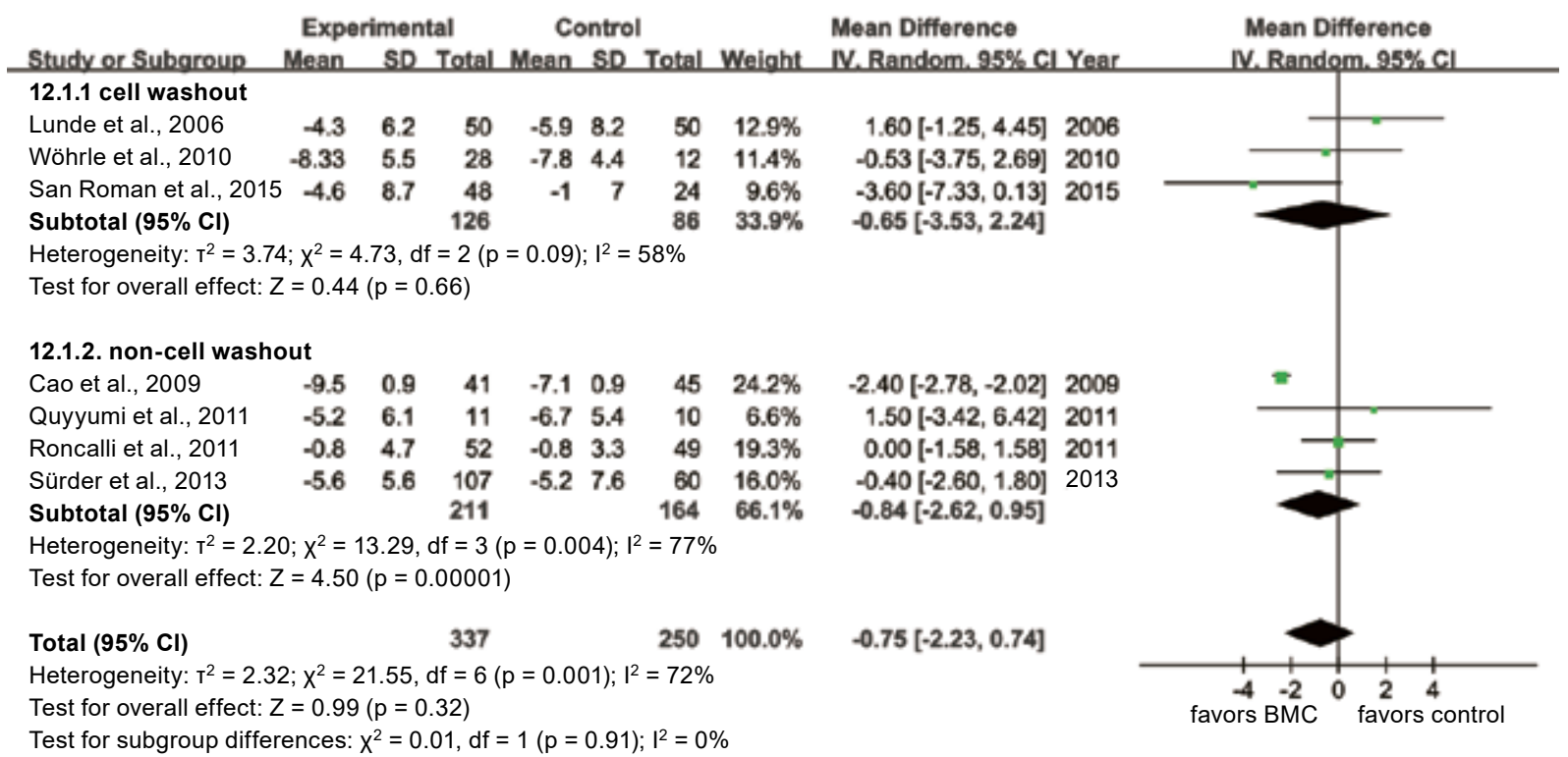

Supplemental Fig. 8.

as a significant decrease in IS, LVESV and LVEDV, which indicated an improvement in left ventricular function and modification in remodeling. Meanwhile, subgroup analysis was performed to determine the effect of se$\mathrm{rum} /$ plasma in intracoronary BMCs therapy. Unfortunately, less benefits in IS and higher all-cause mortality was observed in patients treated with serum/plasma suspended BMCs. Moreover, further subgroup analysis suggested that a more significant decrease of IS was observed in patients treated with non-heparinized intracoronary-admitted BMCs. In the studies using heparin for anticoagulation, all-cause mortality was reported to rise dramatically without the cell washout procedure, although cell washout could not impact the cardiac parameters.

To date, most of the available clinical trials of intracoronary BMCs transplantation result in significant yet modest improvements in LVEF, IS, LVESV and LVEDV, which was confirmed by the present study and other meta-analyses. ${ }^{7,31}$ Further studies indicated that the modest improvement of cardiac function after BMCs transplantation involves low cell survival and impaired cell 


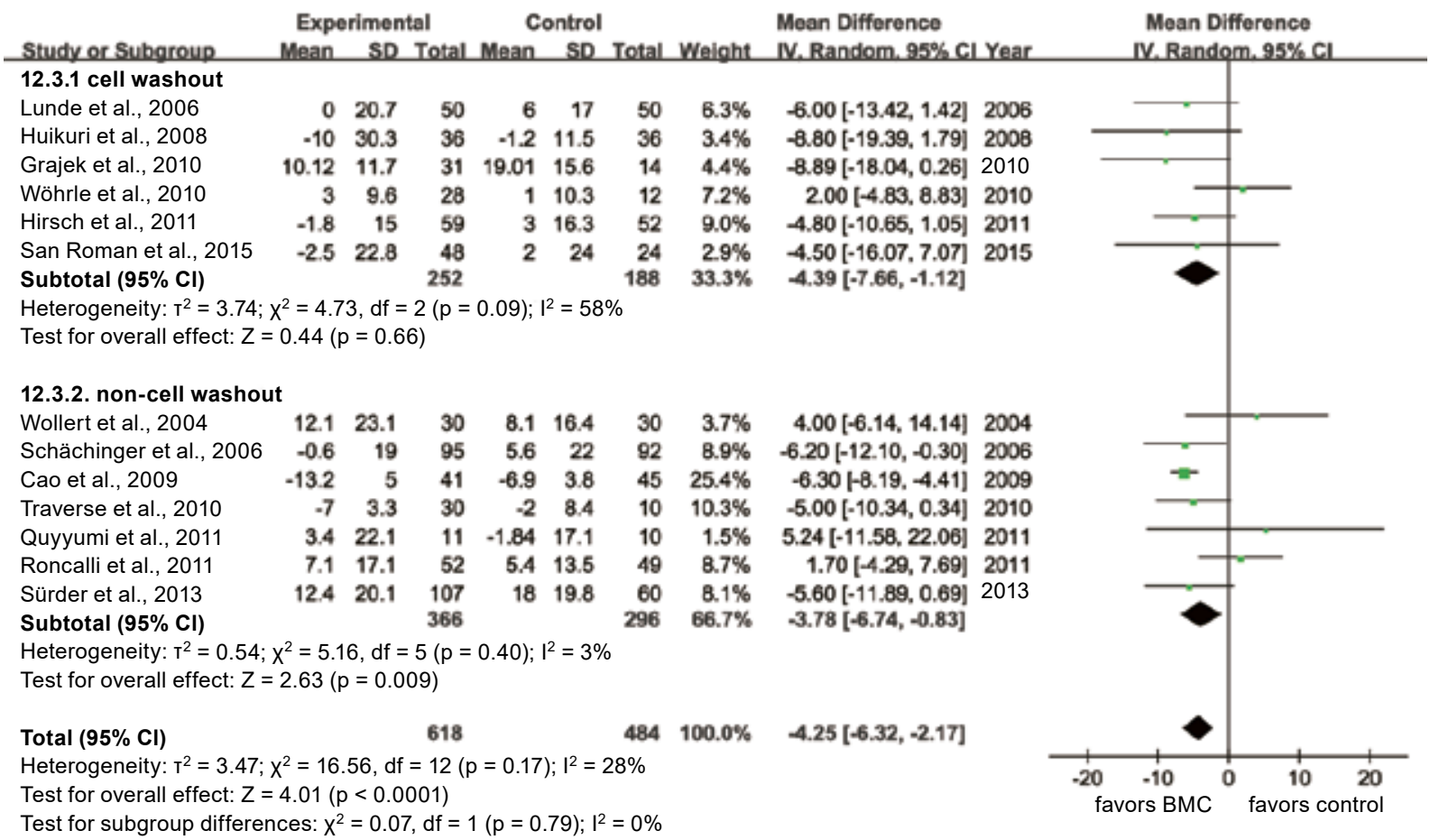

Supplemental Fig. 9.

\begin{tabular}{|c|c|c|c|c|c|c|c|c|c|c|c|}
\hline \multirow[b]{2}{*}{ Study or Subaroup } & \multicolumn{3}{|c|}{ Experimental } & \multicolumn{3}{|c|}{ Control } & \multicolumn{3}{|c|}{ Mean Difference } & \multirow{2}{*}{\multicolumn{2}{|c|}{$\begin{array}{l}\text { Moan Difference } \\
\text { IV. Randem, } 95 \% \mathrm{Cl}\end{array}$}} \\
\hline & Mean & SD & Total & Mean & SD & Tetal & Weight & [V. Random, $95 \% \mathrm{Cl}$ & Year & & \\
\hline \multicolumn{12}{|l|}{ 12.4.1 cell washout } \\
\hline Lunde et al., 2006 & 2 & 28.7 & 50 & 7 & 21.4 & 50 & $7.7 \%$ & $-5.00[-14.92,4.92]$ & 2006 & & \\
\hline Huikuri et al., 2008 & 5.4 & 37.1 & 36 & 8.2 & 34.3 & 36 & $3.7 \%$ & $-2.80[-19.30,13.70]$ & 2008 & & \\
\hline Grajek et al., 2010 & 18.56 & 31 & 31 & 19.52 & 37.2 & 14 & $2.2 \%$ & $-0.96[-23.29,21.37]$ & 2009 & & \\
\hline Wöhrle et al., 2010 & 9.6 & 15.3 & 28 & 10.6 & 14.3 & 12 & $7.7 \%$ & $-1.00[-10.88,8.88]$ & 2010 & & \\
\hline Hirsch et al., 2011 & 3.5 & 16.9 & 59 & 11.2 & 19.8 & 52 & $11.2 \%$ & $-7.70[-14.60,-0.80]$ & 2011 & & \\
\hline San Roman et al., 2015 & 10.2 & 40.8 & 48 & 12 & 32 & 24 & $3.4 \%$ & $-1.80[-19.04,15.44]$ & 2015 & & \\
\hline Subtotal $(95 \% \mathrm{Cl})$ & & & 252 & & & 188 & $35.9 \%$ & $-4.78[-9.23,-0.33]$ & & & \\
\hline \multicolumn{12}{|c|}{$\begin{array}{l}\text { Heterogeneity: } \mathrm{T}^{2}=0.00 ; x^{2}=1.54, \mathrm{df}=5(p=0.91) ; I^{2}=58 \% \\
\text { Test for overall effect: } Z=2.10(p=0.04)\end{array}$} \\
\hline \multicolumn{12}{|l|}{ 12.4.2. non-cell washout } \\
\hline Wollert et al., 2004 & 13.9 & 25.4 & 30 & 7.5 & 17.3 & 30 & $6.7 \%$ & $6.40[-4.60,17.40]$ & 2004 & & \\
\hline Schächinger et al., 2006 & 12 & 31 & 95 & 14 & 33 & 92 & $8.4 \%$ & $-2.00[-11.18,7.18]$ & 2006 & & \\
\hline Cao et al., 2009 & 1.9 & 8.3 & 41 & 4.9 & 5.2 & 45 & $17.2 \%$ & $-3.00[-5.96,-0.04]$ & 2009 & & \\
\hline Traverse et al., 2010 & -4 & 22 & 30 & 17 & 11 & 10 & $7.2 \%$ & $-21.00[-31.41,-10.59]$ & 2010 & & \\
\hline Quyyumi et al., 2011 & 13.4 & 31.3 & 11 & -0.6 & 20.1 & 10 & $2.2 \%$ & $14.00[-8.30,36.30]$ & 2011 & & \\
\hline Roncalli et al., 2011 & 11.5 & 16.4 & 52 & 9.2 & 12.4 & 49 & $13.0 \%$ & $2.30[-3.35,7.95]$ & 2011 & & \\
\hline Sürder et al., 2013 & 19.2 & 33.1 & 107 & 27 & 21.4 & 60 & $9.4 \%$ & $-7.80[-16.09,0.49]$ & 2013 & & \\
\hline Subtotal (95\% Cl) & & & 366 & & & 296 & $64.1 \%$ & $-2.93[-8.46,2.61]$ & & & \\
\hline \multicolumn{12}{|c|}{$\begin{array}{l}\text { Heterogeneity: } \mathrm{T}^{2}=34.19 ; x^{2}=21.17, d f=6(p=0.002) ; I^{2}=72 \% \\
\text { Test for overall effect: } Z=2.63(p=0.009)\end{array}$} \\
\hline Total $(95 \% \mathrm{Cl})$ & & & 618 & & & 484 & $100.0 \%$ & $-3.40[-6.92,0.12]$ & & & \\
\hline \multicolumn{10}{|c|}{$\begin{array}{l}\text { Heterogeneity: } \mathrm{T}^{2}=16.52 ; \mathrm{X}^{2}=23.36, \mathrm{df}=12(p=0.02) ; \mathrm{I}^{2}=49 \% \\
\text { Test for overall effect: } Z=1.89(p<0.06) \\
\text { Test for subgroup differences: } \mathrm{X}^{2}=0.26, \mathrm{df}=1(\mathrm{p}=0.61) ; \mathrm{I}^{2}=0 \%\end{array}$} & $\begin{array}{ll}-20 & -10 \\
\text { favors } & B M C\end{array}$ & $\begin{array}{l}1020 \\
\text { favors control }\end{array}$ \\
\hline
\end{tabular}

Supplemental Fig. 10

function. ${ }^{32}$ Providing near-physiological conditions, and autologous plasma or serum containing growth factors and cytokines gives better results in terms of cell survival and preservation of cellular activities, and thereby it was applied in some clinical trials. ${ }^{14,33,34}$ Therefore, we performed a subgroup analysis based on the cell suspension solution; however, the results showed a greater decrease in IS and a lower risk of all-cause mortality with the non-use of plasma or serum in the final BMC suspension. A recent study indicated that residual clotting activity due to insufficient coagulation during the preparation of autologous serum induced spontaneous clotting of the final cell product, and thus could cause microcirculatory obstructions and subsequent tissue damage 
with intracoronary application. ${ }^{35}$ Notably, delayed clotting of the cell product was observed only in autologous serum from patients with anti-thrombotic therapy, but not from healthy donors or from patients without antithrombotic therapy. ${ }^{35}$ In most clinical trials, the patients who received cell therapy were patients with AMI, routinely provided with anti-thrombotic therapy according to the current guidelines. In the presence of anti-thrombotic drugs, autologous serum was not sufficiently coagulated and induced spontaneous clotting of the final cell product. Therefore, when autologous serum is considered for cell suspension solution, especially for patients with anti-thrombotic therapy, serum preparation should be optimized in order to avoid subsequent clotting of the cell product. Utmost care has to be taken if autologous components are used.

Given that the intracoronary application of stem cells reduced the blood flow or even occluded arteries, probably by causing cell clotting, in some trials, anticoagulant agents like heparin were used during cell preparation with the intention to improve the therapeutic benefits of cell therapy in patients with AMI. ${ }^{15,26,35}$ However, recently it has been indicated that the addition of heparin to stem cell suspension solution might interfere with the SDF-1/CXCR4 axis, thereby resulting in impaired migration and homing of BMCs. Hence, heparin was not recommended by the authors as an ideal anticoagulant. ${ }^{36}$ There are earlier meta-analyses investigating the effect of heparin during cell preparation on LVEF and LVESV, but they arrived at conflict results. Jeevanantham et al. found that heparin in the final BMC suspension brought a greater improvement in LVEF and LVESV. ${ }^{37}$ Contrarily, de Jong et al. suggested that the use of heparin during cell preparation did not seem to affect the therapy outcome. ${ }^{31}$ The inconsistent results might be explained by the authors' different inclusion criteria regarding the cell type, the spectrum of disease and the route of injection. In this study, we focused on the therapeutic effect of BMCs in patients with AMI through an intracoronary infusion of BMCs. A subgroup analysis suggested that a more significant decrease of IS was observed in patients treated with non-heparinized intracoronaryadmitted BMCs. In the studies using heparin for anticoagulation, cell washout significantly lowered all-cause mortality, although this procedure could not impact the cardiac parameters. Since cell washout attenuates heparin and therefore diminishes its effect, it is reasonable to imply that heparin use for cell preparation might be useless or even harmful for the implantation of BMC in AMI patients, probably due to its interference with the SDF-1/CXCR4 axis. ${ }^{36}$ Therefore, if anticoagulant agents are required to reduce potential cell clotting, we could deduce that the application of a new anticoagulant, like Bivalirudin, which does not interfere with the SDF-1/CXCR4 axis, should be of greater benefit for AMI patients undergoing cell therapy.

\section{Conclusions and future perspective}

Methodological differences in adult BMCs transplantation therapy have an impact on the cardiac parameters of patients suffering from an acute myocardial infarction. Non-use of serum or plasma in the cell suspension is associated with better performance in reducing the infarct area and lowering the risk of all-cause mortality. Meanwhile, heparin usage could diminish the benefit of infarct size reduction from BMCs therapy in AMI patients. In studies using heparin for anticoagulation, all-cause mortality rose dramatically without the cell washout procedure, although cell washout could not impact the cardiac parameters.

Further studies are needed to define the optimal components of cell suspension solution required for the maintenance of cell survival and activity. Instead of autologous medium supplements, the use of a combination of cytokines such as VEGF, IGF-1, HGF, SDF-1, PDGF and GCSF, which are known to improve cell activities, may be a preferred option. However, since our understanding and elaboration of the large amount of bioactive components within the serum are far from sufficient, further studies appear to be warranted to determine the optimal cocktail of factors that are required to maintain cell survival and bioactivities. Meanwhile, if new anticoagulant agents, such as Bivalirudin, Rivaroxiban, Apixaban, are required to reduce potential cell clotting, further systematic studies are needed to evaluate their effect on cell functions and long-term outcomes. 


\begin{tabular}{|c|c|c|c|c|c|c|c|c|c|c|c|c|}
\hline 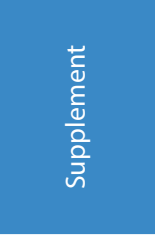 & $\stackrel{\stackrel{\mathscr{E}}{\bar{N}}}{\stackrel{5}{n}}$ & 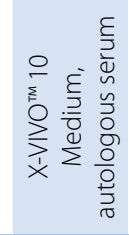 & 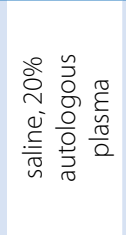 & 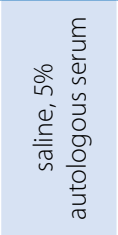 & $\stackrel{\stackrel{\mathscr{c}}{\bar{v}}}{\tilde{\omega}}$ & 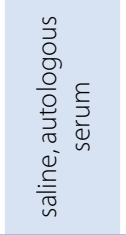 & 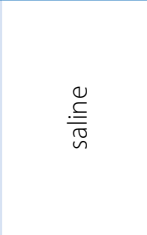 & 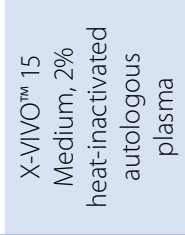 & 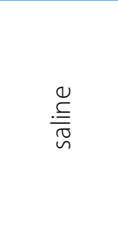 & 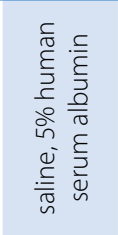 & 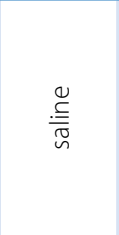 & 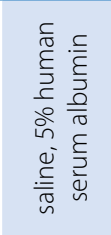 \\
\hline 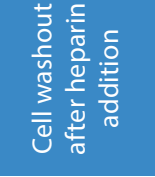 & 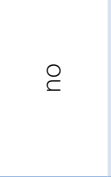 & 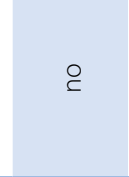 & $\stackrel{\check{\jmath}}{\rightleftharpoons}$ & 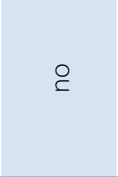 & 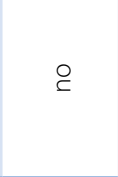 & $\stackrel{\Perp}{\rightleftharpoons}$ & 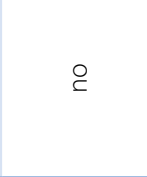 & $\stackrel{๗}{\rightleftharpoons}$ & 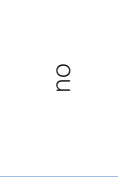 & 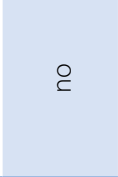 & $\stackrel{\circ}{\complement}$ & $\stackrel{\circ}{ }$ \\
\hline 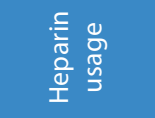 & 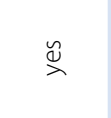 & $\stackrel{\varrho}{\sim}$ & $\stackrel{\check{y}}{\check{\nu}}$ & $\stackrel{\circ}{\complement}$ & $\stackrel{\circ}{\complement}$ & $\stackrel{\varrho}{=}$ & $\stackrel{\circ}{\complement}$ & $\stackrel{\varrho}{~}$ & $\stackrel{\dddot{\aleph}}{\sim}$ & $\stackrel{\circ}{\complement}$ & $\stackrel{\circ}{\complement}$ & $\stackrel{\circ}{\complement}$ \\
\hline 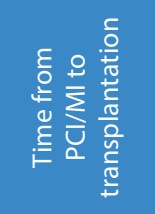 & 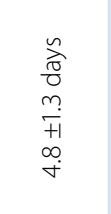 & 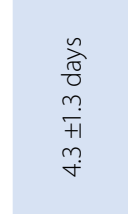 & 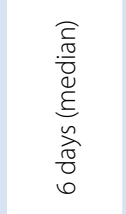 & 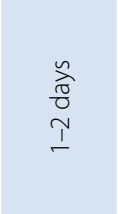 & $\begin{array}{l}n \\
v \\
v\end{array}$ & 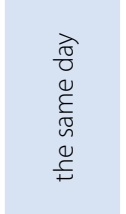 & $\begin{array}{l}\frac{n}{3} \\
\frac{\pi}{0} \\
\frac{0}{1} \\
m\end{array}$ & 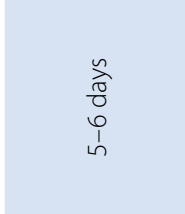 & $\frac{n}{\frac{n}{\pi}}$ & 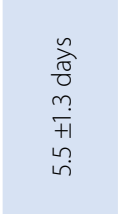 & 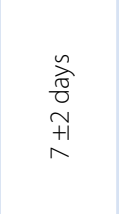 & 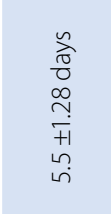 \\
\hline 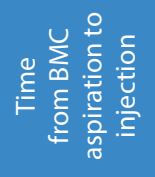 & $\begin{array}{l}c \\
0 \\
0 \\
b\end{array}$ & 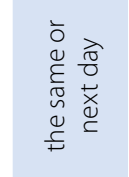 & 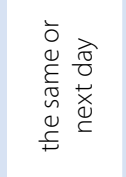 & $\begin{array}{l}\frac{c}{c} \\
\dot{q} \\
\dot{y}\end{array}$ & 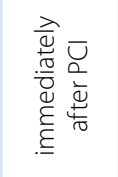 & 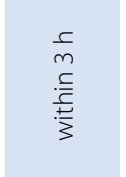 & $\stackrel{r}{\stackrel{c}{d}}$ & 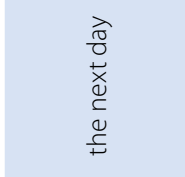 & 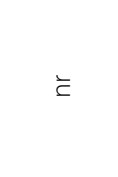 & 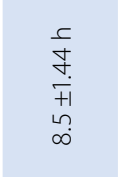 & 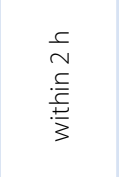 & 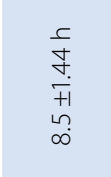 \\
\hline 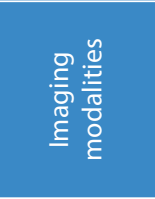 & $\overline{\stackrel{\alpha}{\Sigma}}$ & $\stackrel{\square}{\unlhd}$ & 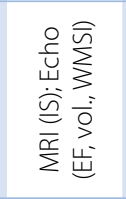 & $\stackrel{\bar{\alpha}}{\Sigma}$ & 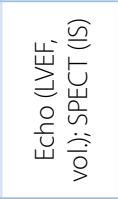 & 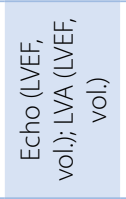 & 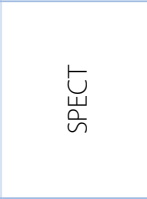 & 祍 & 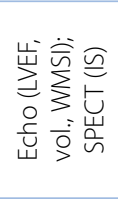 & 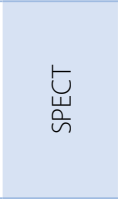 & 号 & 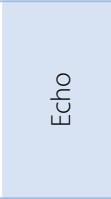 \\
\hline 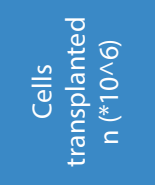 & $\begin{array}{l}0 \\
9 \\
o \\
+1 \\
0 \\
0 \\
1 \\
1\end{array}$ & 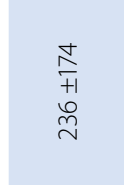 & 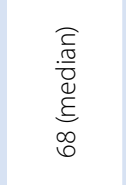 & $\underset{\substack{n \\
\stackrel{+}{N}}}{\stackrel{n}{N}}$ & 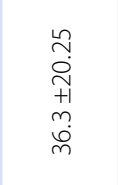 & 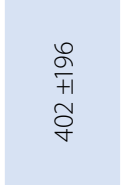 & 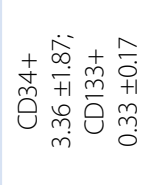 & 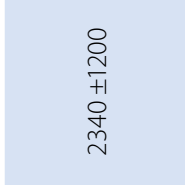 & $\begin{array}{l}\stackrel{0}{1} \\
\stackrel{7}{+1} \\
\stackrel{8}{0} \\
i n\end{array}$ & $\stackrel{\circ}{\circ}$ & $\begin{array}{l}g \\
g \\
+1 \\
\dot{Z} \\
\dot{1}\end{array}$ & ¿. \\
\hline 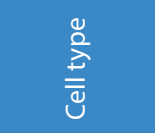 & $\sum_{\infty}^{u}$ & $\sum_{\infty}^{y}$ & $\sum_{\infty}^{y}$ & 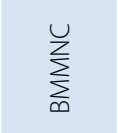 & $\sum_{\infty}^{u}$ & 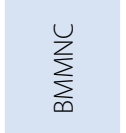 & 尃市 & 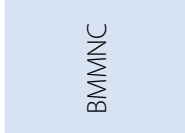 & 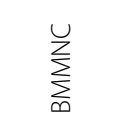 & $\sum_{\infty}^{u}$ & 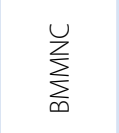 & 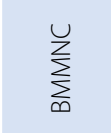 \\
\hline 竧 & $\frac{\frac{0}{0}}{\frac{0}{\bar{T}}}$ & 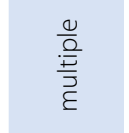 & 高 & $\frac{\frac{0}{0}}{\frac{0}{\bar{T}}}$ & $\frac{\frac{\varrho}{0}}{\frac{\underline{\underline{T}}}{\overrightarrow{\underline{\varepsilon}}}}$ & $\frac{\frac{0}{0}}{\frac{\underline{\underline{T}}}{\overrightarrow{\underline{E}}}}$ & 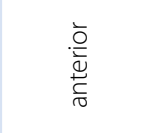 & 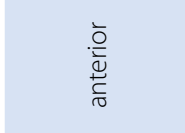 & 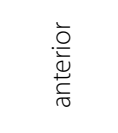 & $\frac{\frac{\varrho}{0}}{\frac{\underline{\underline{T}}}{\overrightarrow{\underline{E}}}}$ & to. & $\frac{\frac{0}{0}}{\frac{0}{\underline{\underline{T}}}}$ \\
\hline 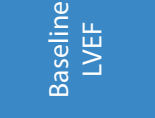 & 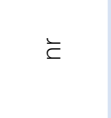 & 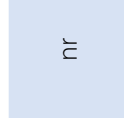 & 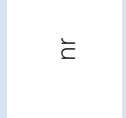 & $\bar{z}$ & 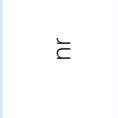 & $\grave{c}$ & 客 & 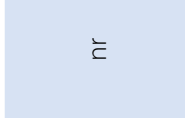 & ¿ & ¿ & 今े & 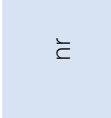 \\
\hline 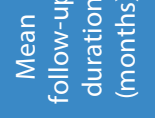 & $\bar{\sigma}$ & $\nabla$ & $\stackrel{\infty}{m}$ & $\nabla$ & 0 & $\bullet$ & 0 & $\simeq$ & $\stackrel{\infty}{+}$ & 0 & 0 & 0 \\
\hline 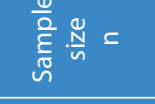 & 8 & 总 & 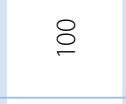 & $\hat{\sigma}$ & ¿ & $\infty$ & $\stackrel{m}{m}$ & ஜ & $\infty$ & i & 8 & i \\
\hline 总 & 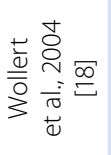 & 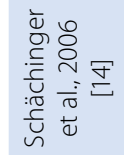 & 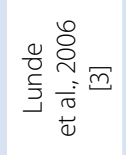 & 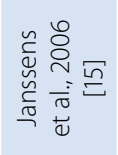 & 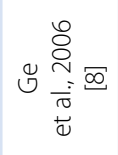 & 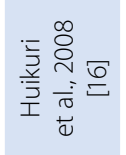 & 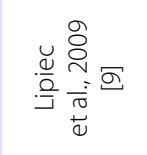 & 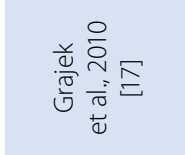 & 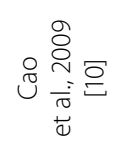 & 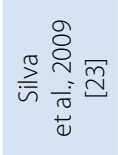 & 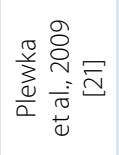 & 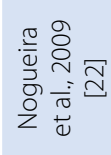 \\
\hline
\end{tabular}




\begin{tabular}{|c|c|c|c|c|c|c|c|c|c|c|c|c|}
\hline 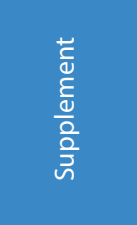 & 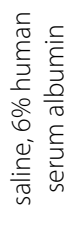 & 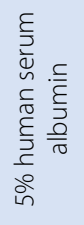 & 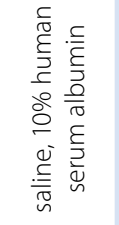 & 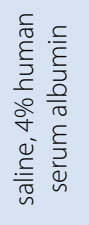 & 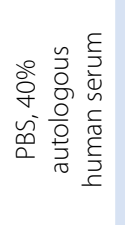 & 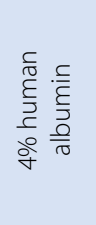 & 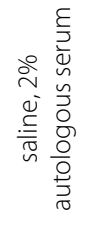 & 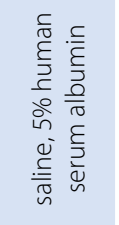 & 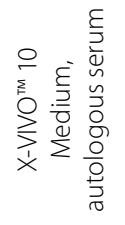 & 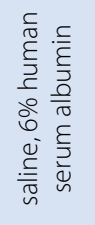 & 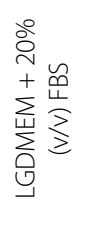 & $\widetilde{\infty}$ \\
\hline 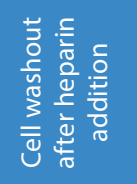 & $\stackrel{\check{\Perp}}{\curvearrowright}$ & $\stackrel{\circ}{\complement}$ & 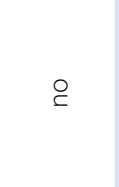 & $\stackrel{\cong}{\beth}$ & $\stackrel{\bigcirc}{\complement}$ & $\stackrel{\circ}{\complement}$ & $\stackrel{\circ}{\complement}$ & ㅇ & $\stackrel{\bigcirc}{\complement}$ & $\stackrel{\circ}{\complement}$ & $\stackrel{\breve{y}}{\lambda}$ & $\stackrel{\breve{y}}{\triangle}$ \\
\hline 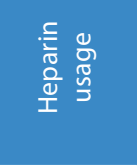 & $\stackrel{\varrho}{\lambda}$ & $\stackrel{\check{\nu}}{\lambda}$ & $\stackrel{\circ}{\complement}$ & $\stackrel{\varpi}{\beth}$ & $\stackrel{\Perp}{\curvearrowright}$ & $\stackrel{\check{\nu}}{\beth}$ & $\stackrel{\circ}{\complement}$ & $\stackrel{\circ}{\complement}$ & $\stackrel{\check{\nu}}{\curvearrowright}$ & $\stackrel{\circ}{\complement}$ & $\stackrel{\breve{\Perp}}{\lambda}$ & $\stackrel{\widetilde{\nu}}{\triangle}$ \\
\hline 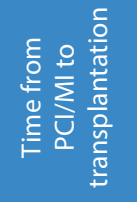 & 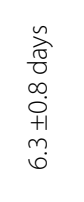 & $\begin{array}{l}\frac{n}{\sqrt{0}} \\
\frac{0}{0} \\
0 \\
\frac{1}{1} \\
m\end{array}$ & 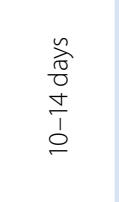 & 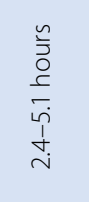 & 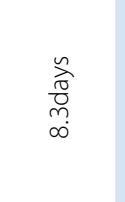 & $\begin{array}{l}\frac{n}{\hat{\sigma}} \\
\frac{0}{0} \\
\frac{1}{+1} \\
m \\
a\end{array}$ & 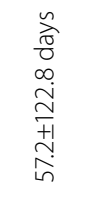 & 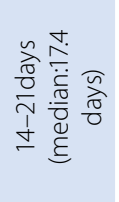 & 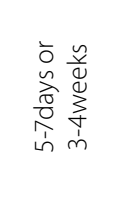 & 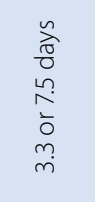 & $\begin{array}{l}\stackrel{n}{\hat{\theta}} \\
\stackrel{0}{0} \\
\stackrel{n}{L}\end{array}$ & 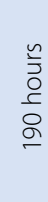 \\
\hline 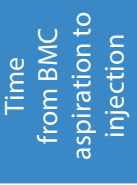 & 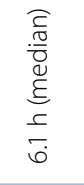 & $\begin{array}{l}\frac{c}{\infty} \\
\infty \\
\stackrel{5}{ \pm} \\
\frac{F}{3} \\
3\end{array}$ & ¿ & 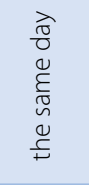 & $\begin{array}{l}c \\
\stackrel{c}{\infty} \\
\stackrel{+}{I} \\
\dot{d}\end{array}$ & 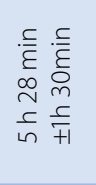 & 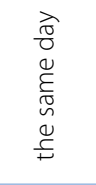 & 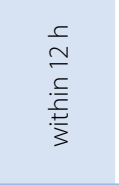 & ¿ & $\underset{\infty}{\stackrel{c}{c}}$ & $\begin{array}{l}\frac{n}{\sqrt{0}} \\
\frac{0}{n}\end{array}$ & 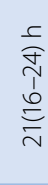 \\
\hline 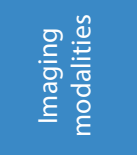 & $\overline{\mathcal{x}_{\Sigma}}$ & $\overline{\stackrel{\mathcal{Y}}{\Sigma}}$ & 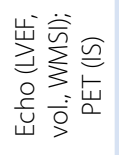 & $\overline{\underline{\Sigma}}$ & $\overline{\underline{\alpha}}$ & $\overline{\stackrel{\alpha}{\Sigma}}$ & $\overline{\underline{\Sigma}}$ & $\overline{\stackrel{\alpha}{\Sigma}}$ & $\overline{\underline{\Sigma}}$ & $\overline{\underline{\Sigma}}$ & $\stackrel{Y}{\geq}$ & $\overline{\widetilde{\alpha}}$ \\
\hline 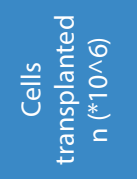 & $\frac{\substack{m \\
+1}}{\frac{\infty}{m}}$ & ㅇ. & 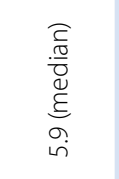 & 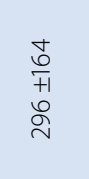 & $\begin{array}{l}\frac{\ln }{5} \\
\frac{0}{0} \\
\text { in }\end{array}$ & $\begin{array}{l}\hat{n} \\
\infty \\
+1 \\
m \\
\infty \\
\infty\end{array}$ & 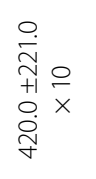 & $\begin{array}{l}\hat{\overline{+1}} \\
\hat{f}\end{array}$ & 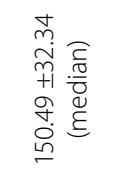 & 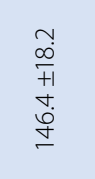 & $\stackrel{\sim}{\text { ¿ }}$ & $\begin{array}{l}\stackrel{8}{0} \\
\text { in } \\
\overline{0} \\
\infty \\
\infty\end{array}$ \\
\hline 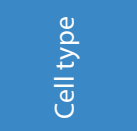 & $\sum_{\infty}^{\bigcup}$ & $\sum_{\infty}^{\bigcup}$ & $\stackrel{+}{\stackrel{m}{D}}$ & $\sum_{\infty}^{\bigcup}$ & 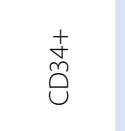 & $\sum_{\infty}^{\bigcup}$ & $\sum_{\infty}^{\bigcup}$ & $\sum_{\infty}^{\bigcup}$ & $\sum_{\infty}^{\bigcup}$ & $\sum_{\infty}^{\bigcup}$ & $\sum_{\infty}^{\cup}$ & $\sum_{\infty}^{\longleftarrow}$ \\
\hline & $\frac{0}{2}$ & & & $\stackrel{0}{\simeq}$ & $\stackrel{0}{2}$ & $\stackrel{0}{\simeq}$ & $\stackrel{0}{\simeq}$ & $\stackrel{\Theta}{\Omega}$ & $\ddot{\nu}$ & $\stackrel{0}{2}$ & 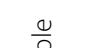 & 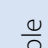 \\
\hline
\end{tabular}

\begin{tabular}{|c|c|c|c|c|c|c|c|c|c|c|c|c|}
\hline 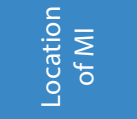 & $\frac{\frac{0}{.0}}{\frac{.0}{\frac{D}{3}}}$ & 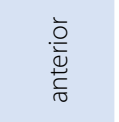 & 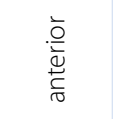 & $\frac{\frac{0}{O}}{\frac{O}{\frac{O}{J}}}$ & 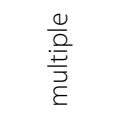 & 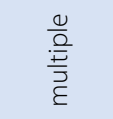 & 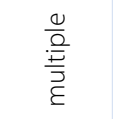 & 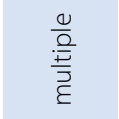 & $\frac{\frac{0}{\rho}}{\frac{?}{\vec{n}}}$ & $\frac{\frac{0}{a}}{\frac{?}{\frac{a}{2}}}$ & $\frac{\frac{0}{a}}{\frac{?}{\frac{a}{2}}}$ & $\frac{\frac{0}{2}}{\frac{?}{\frac{1}{2}}}$ \\
\hline 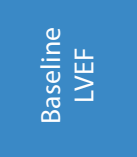 & 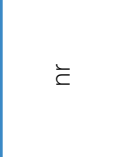 & $\begin{array}{l}\stackrel{\circ}{ } \\
\text { Wे }\end{array}$ & $\begin{array}{l}\stackrel{\circ}{\stackrel{े}{े}} \\
\text { VI }\end{array}$ & ¿ & $\begin{array}{l}\text { Oे } \\
\text { के } \\
\text { Vil }\end{array}$ & 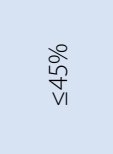 & $\begin{array}{l}\stackrel{\circ}{\circ} \\
\text { Vे }\end{array}$ & 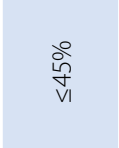 & $\stackrel{\stackrel{\leftrightarrow}{\vee}}{\stackrel{\leftrightarrow}{v}}$ & 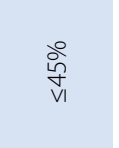 & 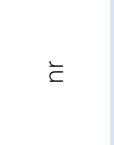 & ¿ \\
\hline 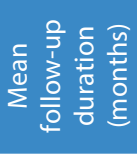 & 0 & $\bullet$ & $\simeq$ & $\nabla$ & $\bullet$ & $m$ & $\bullet$ & $\bullet$ & $\nabla$ & $\simeq$ & 6 & $\simeq$ \\
\hline$\frac{\frac{\varrho}{\circ}}{\frac{E}{N}} \frac{\stackrel{N}{N}}{n}=$ & ช & 아 & $\stackrel{\circ}{\circ}$ & $\stackrel{\sim}{m}$ & $\bar{m}$ & 드 & $\stackrel{\varpi}{\sim}$ & $\widehat{\infty}$ & $\stackrel{\Xi}{\sigma}$ & $\stackrel{\beth}{\beth}$ & $\stackrel{\infty}{i n}$ & ৪ \\
\hline 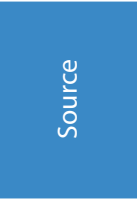 & 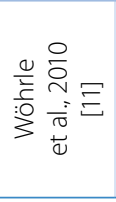 & 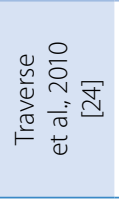 & 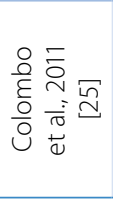 & 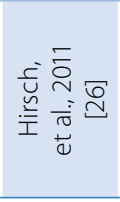 & 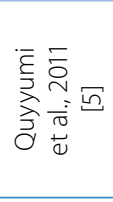 & 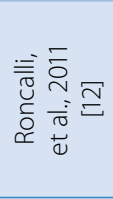 & 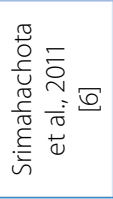 & 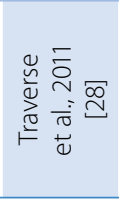 & 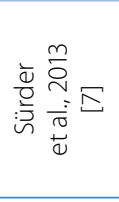 & 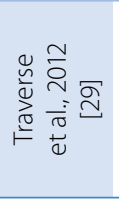 & 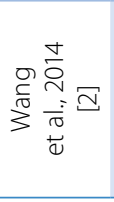 & 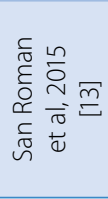 \\
\hline
\end{tabular}


Supplemental Table B. Quality assesment of the studies included in the meta-analysis according to Juni criteria

\begin{tabular}{|c|c|c|c|c|c|c|c|}
\hline Source & $\begin{array}{l}\text { Was allocation } \\
\text { adequate? }\end{array}$ & $\begin{array}{c}\text { Was an } \\
\text { adequate } \\
\text { method of } \\
\text { randomization } \\
\text { described? }\end{array}$ & $\begin{array}{l}\text { Were the } \\
\text { groups similar } \\
\text { at the start of } \\
\text { the study? }\end{array}$ & $\begin{array}{l}\text { Were patients/ } \\
\text { caregivers } \\
\text { blinded for } \\
\text { intervention? }\end{array}$ & $\begin{array}{l}\text { Was outcome } \\
\text { ascertained } \\
\text { blinded? }\end{array}$ & $\begin{array}{c}\text { What } \\
\text { percentage } \\
\text { was lost in the } \\
\text { follow up? } \\
(\%)\end{array}$ & $\begin{array}{l}\text { Were all } \\
\text { patients } \\
\text { analyzed in the } \\
\text { group to which } \\
\text { they were } \\
\text { assigned? }\end{array}$ \\
\hline $\begin{array}{l}\text { Wollert et al., } \\
2004 \text { [18] }\end{array}$ & Y & Y & Y & Y & Y & 0 & Y \\
\hline $\begin{array}{l}\text { Schächinger et al., } \\
2006 \text { [14] }\end{array}$ & Y & Y & Y & Y & Y & 0 & Y \\
\hline $\begin{array}{l}\text { Lunde et al., } \\
2006[3]\end{array}$ & Y & Y & Y & N & Y & 3 & Y \\
\hline $\begin{array}{l}\text { Janssens et al., } \\
2006 \text { [15] }\end{array}$ & Y & Y & Y & Y & Y & 10.4 & Y \\
\hline $\begin{array}{l}\text { Ge et al., } \\
2006[8]\end{array}$ & Y & Y & Y & Y & Y & 0 & Y \\
\hline $\begin{array}{l}\text { Huikuri et al., } \\
2008 \text { [16] }\end{array}$ & Y & Y & Y & Y & Y & 3.7 & Y \\
\hline $\begin{array}{l}\text { Lipiec et al., } \\
2009 \text { [9] }\end{array}$ & Y & Y & Y & N & Y & 5.6 & N \\
\hline $\begin{array}{l}\text { Grajek et al., } \\
2009 \text { [17] }\end{array}$ & Y & Y & Y & N & Y & 0 & $\mathrm{~N}$ \\
\hline $\begin{array}{l}\text { Cao et al., } \\
2009 \text { [10] }\end{array}$ & Y & Y & Y & $\mathrm{nr}$ & Y & 0 & Y \\
\hline $\begin{array}{l}\text { Silva et al., } \\
2009 \text { [23] }\end{array}$ & Y & Y & Y & N & Y & 0 & Y \\
\hline $\begin{array}{l}\text { Plewka et al., } \\
2009 \text { [21] }\end{array}$ & Y & N & Y & N & Y & 0 & Y \\
\hline $\begin{array}{l}\text { Nogueira et al., } \\
2009 \text { [22] }\end{array}$ & Y & Y & Y & N & Y & 0 & Y \\
\hline $\begin{array}{l}\text { Wöhrle et al., } \\
2010 \text { [11] }\end{array}$ & Y & Y & Y & Y & Y & 0 & Y \\
\hline $\begin{array}{l}\text { Traverse et al., } \\
2010 \text { [24] }\end{array}$ & Y & Y & Y & Y & Y & 0 & Y \\
\hline $\begin{array}{l}\text { Colombo et al., } \\
2011 \text { [25] }\end{array}$ & Y & Y & Y & N & Y & 0 & Y \\
\hline $\begin{array}{l}\text { Hirsch et al., } \\
2011 \text { [26] }\end{array}$ & Y & Y & Y & N & Y & 0 & Y \\
\hline $\begin{array}{l}\text { Quyyumi et al., } \\
2011 \text { [5] }\end{array}$ & Y & N & Y & N & Y & 0 & N \\
\hline $\begin{array}{l}\text { Roncalli et al., } \\
2011 \text { [12] }\end{array}$ & Y & Y & Y & N & Y & 4 & Y \\
\hline $\begin{array}{c}\text { Srimahachota et al., } \\
2011[6]\end{array}$ & Y & N & Y & N & Y & 0 & Y \\
\hline $\begin{array}{c}\text { Traverse et al., } \\
2011 \text { [28] }\end{array}$ & Y & N & Y & N & Y & 1.1 & Y \\
\hline $\begin{array}{l}\text { Sürder et al., } \\
\quad 2012 \text { [7] }\end{array}$ & Y & Y & Y & N & Y & 0 & Y \\
\hline $\begin{array}{l}\text { Traverse et al., } \\
2012 \text { [29] }\end{array}$ & Y & N & Y & Y & Y & 10 & Y \\
\hline $\begin{array}{l}\text { Wang et al., } \\
2014 \text { [2] }\end{array}$ & Y & Y & Y & Y & $\mathrm{nr}$ & 0 & Y \\
\hline $\begin{array}{l}\text { San Roman et al., } \\
2015 \text { [13] }\end{array}$ & Y & Y & Y & Y & Y & 0 & $\mathrm{~N}$ \\
\hline
\end{tabular}

$\mathrm{Y}$-yes; $\mathrm{N}$ - no; nr -not reported. 


\section{References}

1. Juni P, Altman DG, Egger M. Systematic reviews in health care: Assessing the quality of controlled clinical trials. BMJ. 2001;323:42-46.

2. Wang X, Xi WC, Wang F. The beneficial effects of intracoronary autologous bone marrow stem cell transfer as an adjunct to percutaneous coronary intervention in patients with acute myocardial infarction. Biotechnol Lett. 2014;36:2163-2168.

3. Lunde K, Solheim S, Aakhus S, et al. Intracoronary injection of mononuclear bone marrow cells in acute myocardial infarction. NEngl J Med. 2006;355:1199-1209.

4. Beitnes JO, Hopp E, Lunde $\mathrm{K}$, et al. Long-term results after intracoronary injection of autologous mononuclear bone marrow cells in acute myocardial infarction: The ASTAMI randomised, controlled study. Heart. 2009;95:1983-1989.

5. Quyyumi AA, Waller EK, Murrow J. CD34(+) cell infusion after ST elevation myocardial infarction is associated with improved perfusion and is dose dependent. Am Heart J. 2011;161:98-105.

6. Srimahachota S, Boonyaratavej S, Rerkpattanapipat $P$, et al. Intra coronary bone marrow mononuclear cell transplantation in patients with ST-elevation myocardial infarction: A randomized controlled study. J Med Assoc Thai. 2011;94:657-663.

7. Sürder D, Manka R, Lo Cicero V, et al. Intracoronary injection of bone marrow-derived mononuclear cells early or late after acute myocardial infarction: Effects on global left ventricular function. Circulation. 2013;127:1968-1979.

8. Ge J, Li Y, Qian J, et al. Efficacy of emergent transcatheter transplantation of stem cells for treatment of acute myocardial infarction (TCTSTAMI). Heart. 2006;92:1764-1767.

9. Lipiec $P$, Krzemińska-Pakuła M, Plewka M, et al. Impact of intracoronary injection of mononuclear bone marrow cells in acute myocardial infarction on left ventricular perfusion and function: A 6-month follow-up gated 99mTc-MIBI single-photon emission computed tomography study. Eur J Nucl Med Mol Imaging. 2009;36:587-593.

10. Cao F, Sun D, Li C, et al. Long-term myocardial functional improvement after autologous bone marrow mononuclear cells transplantation in patients with ST-segment elevation myocardial infarction: 4-year follow-up. Eur Heart J. 2009;30:1986-1994.

11. Wöhrle J, Merkle N, Mailänder V, et al. Results of intracoronary stem cell therapy after acute myocardial infarction. Am J Cardiol. 2010;105:804-812.

12. Roncalli J, Mouquet F, Piot C, et al. Intracoronary autologous mononucleated bone marrow cell infusion for acute myocardial infarction: Results of the randomized multicenter BONAMI trial. Eur Heart J. 2011;32:1748-1757.

13. San Roman JA, Sánchez PL, Villa A, et al.; Comparison of different bone marrow-derived stem cell approaches in reperfused STEMI: A multicenter, prospective, randomized, open-labeled TECAM trial. J Am Coll Cardiol. 2015;65:2372-2382.

14. Schächinger V, Erbs S, Elsässer A, et al. REPAIR-AMI Investigators. Improved clinical outcome after intracoronary administration of bonemarrow-derived progenitor cells in acute myocardial infarction: Final 1-year results of the REPAIR-AMI trial. Eur Heart J. 2006;27:2775-2783.

15. Janssens S, Dubois C, Bogaert J, et al. Autologous bone marrowderived stem-cell transfer in patients with ST-segment elevation myocardial infarction: Double-blind, randomised controlled trial. Lancet. 2006;367:113-121.

16. Huikuri HV, Kervinen K, Niemelä M, et al.; FINCELL Investigators. Effects of intracoronary injection of mononuclear bone marrow cells on left ventricular function, arrhythmia risk profile, and restenosis after thrombolytic therapy of acute myocardial infarction. Eur Heart J. 2008;29:2723-2732.

17. Grajek S, Popiel M, Gil L, et al. Influence of bone marrow stem cells on left ventricle perfusion and ejection fraction in patients with acute myocardial infarction of anterior wall: Randomized clinical trial. Impact of bone marrow stem cell intracoronary infusion on improvement of microcirculation. Eur Heart J. 2010;31:691-702.

18. Wollert KC, Meyer GP, Lotz J, et al. Intracoronary autologous bonemarrow cell transfer after myocardial infarction: The BOOST randomised controlled clinical trial. Lancet. 2004;364:141-148.

19. Meyer GP, Wollert KC, Lotz J, et al. Intracoronary bone marrow cell transfer after myocardial infarction: Eighteen months' follow-up data from the randomized, controlled BOOST (BOne marrOw transfer to enhance ST-elevation infarct regeneration) trial. Circulation. 2006;113:1287-1294.
20. Meyer GP, Wollert KC, Lotz J, et al. Intracoronary bone marrow cell transfer after myocardial infarction: 5-year follow-up from the randomized-controlled BOOST trial. Eur Heart J. 2009;30:2978-2984.

21. Plewka M, Krzemińska-Pakuła M, Lipiec $P$, et al. Effect of intracoronary injection of mononuclear bone marrow stem cells on left ventricular function in patients with acute myocardial infarction. Am J Cardiol. 2009;104:1336-1342.

22. Nogueira FB, Silva SA, Haddad AF, et al. Systolic function of patients with myocardial infarction undergoing autologous bone marrow transplantation. Arq Bras Cardiol. 2009;93:367-372.

23. Silva SA, Sousa AL, Haddad AF, et al. Autologous bone-marrow mononuclear cell transplantation after acute myocardial infarction: Comparison of two delivery techniques. Cell Transplant. 2009;18:343-352.

24. Traverse JH, McKenna DH, Harvey $\mathrm{K}$, et al. Results of a phase 1, randomized, double-blind, placebo-controlled trial of bone marrow mononuclear stem cell administration in patients following ST-elevation myocardial infarction. Am Heart J. 2010;160:428-434.

25. Colombo A, Castellani M, Piccaluga E, et al. Myocardial blood flow and infarct size after CD133+ cell injection in large myocardial infarction with good recanalization and poor reperfusion: Results from a randomized controlled trial. J Cardiovasc Med (Hagerstown). 2011;12:239-248.

26. Hirsch A, Nijveldt R, van der Vleuten PA, et al.; HEBE Investigators. Intracoronary infusion of mononuclear cells from bone marrow or peripheral blood compared with standard therapy in patients after acute myocardial infarction treated by primary percutaneous coronary intervention: Results of the randomized controlled HEBE trial. Eur Heart J. 2011;32:1736-1747.

27. Delewi R, van der Laan AM, Robbers LF, et al.; HEBE investigators. Long term outcome after mononuclear bone marrow or peripheral blood cells infusion after myocardial infarction. Heart. 2015;101:363-368.

28. Traverse JH, Henry TD, Ellis SG, et al. Cardiovascular Cell Therapy ResearchNetwork: Effect of intracoronary delivery of autologous bone marrow mononuclear cells 2 to 3 weeks following acute myocardial infarction on left ventricular function: The late TIME randomized trial. JAMA. 2011;306:2110-2119.

29. Traverse JH, Henry TD, Pepine CJ, et al.; Cardiovascular Cell Therapy Research Network (CCTRN). Effect of the use and timing of bone marrow mononuclear cell delivery on left ventricular function after acute myocardial infarction: The TIME randomized trial. JAMA. 2012;308:2380-2389.

30. Traverse JH, Henry TD, Pepine CJ, Willerson JT, Ellis SG. One-year follow-up of intracoronary stem cell delivery on left ventricular function following ST-elevation myocardial infarction. JAMA. 2014;311:301-302.

31. De Jong R, Houtgraaf JH, Samiei S, Boersma E, Duckers HJ. Intracoronary stem cell infusion after acute myocardial infarction: A meta-analysis and update on clinical trials. Circ Cardiovasc Interv. 2014;7:156-167.

32. Xu Q, Seeger FH, Castillo J, et al. Micro-RNA-34a contributes to the impaired function of bone marrow-derived mononuclear cells from patients with cardiovascular disease. J Am Coll Cardiol. 2012;59:2107-2117.

33. Seeger FH, Tonn T, Krzossok N, Zeiher AM, Dimmeler S. Cell isolation procedures matter: A comparison of different isolation protocols of bone marrow mononuclear cells used for cell therapy in patients with acute myocardial infarction. Eur Heart J. 2007;28:766-772.

34. Assmus B, Walter $\mathrm{DH}$, Seeger FH, et al. Effect of shock wave-facilitated intracoronary cell therapy on LVEF in patients with chronic heart failure: The CELLWAVE randomized clinical trial.JAMA. 2013;309:1622-1631.

35. Seeger FH, Rasper T, Bönig H, Assmus B, Zeiher AM, Dimmeler S. The challenges of autologous cell therapy: Systemic anti-thrombotic therapies interfering with serum coagulation may disable autologous serum-containing cell products for therapeutical use. J Cardiovasc Transl Res. 2014;7:644-650.

36. Seeger FH, Rasper T, Fischer A, et al. Heparin disrupts the cxcr4/ sdf- 1 axis and impairs the functional capacity of bone marrowderived mononuclear cells used for cardiovascular repair. Circ Res. 2012;111:854-862.

37. Jeevanantham V, Butler M, Saad A, Abdel-Latif A, Zuba-Surma EK, Dawn B. Adult bone marrow cell therapy improves survival and induces long-term improvement in cardiac parameters: A systematic review and meta-analysis. Circulation. 2012;126:551-568. 